\title{
Brexit and the Banking Sector: The Stock Market Reaction of UK and European Banks
}

\author{
Doriana Cucinelli ${ }^{1}$, Paola Schwizer ${ }^{2} \&$ Maria Gaia Soana ${ }^{3}$ \\ ${ }^{1}$ Assistant Professor, Banking and Finance, University of Parma, Via J.F.K Kennedy, Parma, Italy \\ ${ }^{2}$ Full Professor, Banking and Finance, University of Parma, Via J.F.K Kennedy, Parma, Italy \\ ${ }^{3}$ Associate Professor, Banking and Finance, University of Parma, Via J.F.K Kennedy, Parma, Italy \\ Correspondence: Maria Gaia Soana, Associate Professor, Banking and Finance, University of Parma, Via J.F.K \\ Kennedy, Parma, Italy. E-mail: mariagaia.soana@unipr.it
}

Received: December 18, 2020

Accepted: January 25, 2021

Online Published: March 11, 2021

doi:10.5539/ijbm.v16n4p27

URL: https://doi.org/10.5539/ijbm.v16n4p27

\begin{abstract}
We examine the impact of three events related to Brexit on stock prices of UK and European banks: i) the announcement of the referendum date, ii) the referendum result, and iii) the appointment of Theresa May as the British Prime Minister. Our results show that bank shareholders reacted positively to the announcement of the referendum date and to the election of Theresa May as Prime Minister, whereas their reaction to the referendum outcome was negative. The analysis also demonstrates that the impact of different stages of Brexit on the stock market is more dependent on geographical factors than on firm-specific characteristics. The only exception is bank size, which positively affects bank shareholder choices. Our results have important regulatory and managerial implications: new political risks should be appropriately included into scenario analysis and the ability to assess and manage this risk should be taken into account in strategic planning and risk management.
\end{abstract}

Keywords: Brexit, event study, stock market reaction, banks

\section{Introduction}

The debate on the efficient market hypothesis, which began at the end of the 1960s (Fama, 1965, 1970), remains unresolved. In this context, a large body of literature has investigated the different variables that affect share prices, returns, and volatility (among others, see Errunza \& Hogan, 1998; Guldiken, Tupper, Nair \& Yu, 2017). Harvey, Campbell, Liu, \& Heqing (2016) assert that more than 300 factors, including political, economic, and social considerations, can influence stock market dynamics. Brexit, a political event with potential critical economic and social consequences, is among these factors, as suggested by several authors (among others see Schiereck, Kiesel, \& Kolaric, 2016; Oehler, Horn, \& Wendt, 2017; Ramiah, Huy, Pham, \& Moosa, 2017; Tielman \& Schiereck, 2017; Hill, Korczal A., \& Korczak P., 2019).

The Brexit referendum was held on 23 June 2016, and had a largely unexpected outcome: 17.4 million British citizens $(51.89 \%)$ made the decision to leave the European Union (EU). The path that led to the UK referendum of 2016 can be dated long back, possibly even to the very beginning of the UK membership of the European community. The people and politicians of the UK were divided with regard to the value of this membership, and the 2008 financial crisis and the consequent sovereign debt crisis of a few European countries intensified this debate, as likely did the increased level of migration into the UK. In 2013, Britain's then-Prime-Minister David Cameron promised that if his Conservative Party won the general election, he would hold a referendum on whether the UK should remain in the EU or leave. When the Conservative Party won, he kept his promise, although supporting "remain", i.e. the UK's continued membership of the EU: "It will be stronger if we stay. It will be weaker if we leave." declared Cameron on 21 June 2016, in his last-ditch speech calling for Britain to remain (Note $1)$.

The result of the Brexit vote caused substantial turmoil in financial markets, both in the UK and other countries: by 27 June 2016, the FTSE 100 index fell by 3.2\% (losing nearly $£ 85$ billion), the German DAX by $6.8 \%$, and the Dow Jones Industrial Average by 3.4\%. Likewise, on 24 June 2016, in early trades, the IBEX 35, Greek ATHEX, Dutch AEX index, Czech PX Index, and Polish WIG30 all fell by $8 \%$ to $15 \%$, and the sterling reached its lowest level against the US dollar since 1985. 
The banking sector was one of the most strongly affected industries. Financial services are in fact a critical sector of the UK's economy, accounting for 7-12 per cent of the country's GDP, 11 per cent of its gross tax receipts, and 7-12 per cent of employment (House of Lords EU Committee, 2016; Oliver Wyman, 2016). Financial services also provide the largest trade surplus of any sector of the UK economy, valued at $£ 58$ billion in 2014, of which $£ 19$ billion relates to trade with the rest of the EU (Oliver Wyman, 2016). Therefore, it is unsurprising that, before the referendum, the four largest UK banks - HSBC, Royal Bank of Scotland (RBS), Barclays, and Lloyds TSB - strongly opposed Brexit. Many US banks were also vocal opponents of Brexit. In 2016, approximately $90 \%$ of both European turnover and the employees of the five largest US investment banks (Goldman Sachs, JP Morgan, Citigroup, Morgan Stanley, and Bank of America Merrill Lynch) were in fact located in London (Howarth \& Quaglia, 2018). They used the UK as a point of entry into the European single market through UK-based subsidiaries, and feared that Brexit would damage their business in Europe and/or induce expense and disruption due to the need for relocation of their offices to other European countries. Moreover, it was often argued that Brexit would not only damage the UK banking sector, but also impair the financing of the entire European economy.

By the end of 24 June 2016, the share prices of the Royal Bank of Scotland dropped by approximately $18.0 \%$, while those of Barclays and Deutsche Bank fell by $17.7 \%$ and $13.9 \%$, respectively. This strong impact can be explained by considering that UK is the largest exporter of financial services in the world, and one-third of its export is directed to the EU (Armour, 2017; Howarth \& Quaglia, 2018). Therefore, UK firms would have found it considerably more expensive to export to the EU in a Brexit scenario. This would also have represented a loss to the EU27, because the UK specializes in capital markets services that the EU, which is over-reliant on banking, has always used (Armour, 2017). Consequently, the announcement of the referendum outcome raised strong concerns around the future of the financial system, both in the UK and the EU.

The negative effects of Brexit on the banking industry could stem from several factors. First, it might affect business continuity and increase transitional risks for the Euro area and UK banks. Second, it could enhance macroeconomic and regulatory risks, including potential regulatory arbitrage: bank clients, suppliers, and commercial partners would all be affected. Third, it might have unpredictable consequences for small businesses. While most banks immediately took contingency measures to ensure that their business continued to run after Brexit, many European small- and medium-sized enterprises are unprepared for the disruption and potential negative impact of Brexit on their business: their decisions, which are difficult to predict or control for, might shape the business models that banks could adopt after the final Brexit negotiations.

In addition, over the last few years, the European Central Bank (ECB) has identified the "Brexit-related risk" as one of the key challenges for supervised entities, including it among its supervisory priorities. Even before the referendum of 23 June 2016, which resulted in the UK leaving the EU, this risk was on the radar of the financial sector, although the possibility of the UK deciding to leave the EU was generally considered remote. Nevertheless, the ECB immediately started to monitor whether and how banks would be affected by this geo-political risk, and whether they would be able to address related issues in a timely manner, if needed, through Brexit-driven change management processes.

In its 2020 risk map (Note 2), the ECB states that uncertainty around the UK's membership of the EU remains high. Tail risks appear to be concentrated in particular countries and banks with close links to the UK. Furthermore, it is also true that some banks are behind schedule in implementing their contingency plans and need to step up their preparations, including transferring staff and strengthening local risk management capabilities and governance structures.

Analysis of the stock market reaction to political events is crucial for banks to forecast future possible scenarios. In the last few decades, the EU has experienced several political events affecting stock market dynamics: among these, Brexit represents one of the most important, and can be a black swan. For this reason, the study of the stock market reaction to the announcements of events related to Brexit is important both for policy makers and investors: the former could adjust economic policy measures aimed at achieving the stability of financial markets and the economy as a whole, while the latter might plan their portfolio and risk management activities (Škrinjari'c, 2020).

In this context, our paper aims to investigate bank shareholder reaction to some events relating to Brexit, distinguishing between UK and other European banks. Specifically, we attempted to answer the following questions: i) How did bank shareholders react to the most important events related to Brexit? ii) Are there differences between UK and other European banks in relation to their reactions to Brexit-related events? iii) Can firm characteristics explain bank stock reactions to Brexit-related events? 
Using a sample of 46 and 167 listed banks from the UK and other European countries, respectively, we carry out event studies on three different events related to Brexit, i.e. the announcement of the referendum (20 February 2016), the referendum result (23 June 2016), and the day on which Theresa May became the UK Prime Minister (11 July 2016). We also conduct ordinary least squares (OLS) regression analyses to investigate the possible determinants of average cumulative abnormal returns.

Our results show that bank shareholders reacted positively to the announcement of the referendum date and to the election of Theresa May as Prime Minister, whereas their reaction to the referendum outcome was negative. The analysis also demonstrates that the impact of different stages of Brexit on the stock market is more dependent on geographical factors than on firm-specific characteristics: the only exception to this is bank size, which positively affects bank shareholder choices.

Our study contributes to the ongoing debate about the stock market reaction to geo-political events. First, we focus on the impact of Brexit on the banking sector, without considering other industries. This focus is based on the assumption that the banking sector is particularly vulnerable to the consequences of the referendum, because the City of London is the most important European financial center. Second, the research considers three different significant dates to analyze the impact of Brexit on stock market returns. Unlike that of most previous studies, our focus is therefore not exclusively on the referendum event, but on different Brexit-related events over a longer time horizon from 20 February 2016 to 7 September 2018. Third, we observe the effect of Brexit both in the UK and in other European countries and attempt to explain the differences in these effects between these countries. Finally, we investigate the possible impact of firm- and country-specific characteristics on bank shareholder reactions.

The paper is organized as follows. Section 2 presents the literature review, while the sample and the methodology are reported in Section 3. Our main results are discussed in Section 4, and the additional analysis and robustness checks are described in Section 5. Finally, our conclusion and discussion are reported in Section 6.

\section{Literature Review}

Our paper focuses on the effect of the Brexit referendum on bank stock returns. There are two strands of literature about Brexit, studying its effects: i) on stock market volatility, based on the assumption that the referendum outcome heralded a period of political uncertainty (Krause et al., 2016; Schiereck et al., 2016; Smales, 2017; Dibiasi, Abberger, Siegenthaler, \& Sturm, 2018), and ii) on stock market prices, investigating the consequences of Brexit as geo-political and economic event.

The papers of the first strand of the literature (Pastor \& Veronesi, 2012; Wielechowski \& Czech, 2016) identify all of the Brexit-related changes by the government, including the time horizon from the announcement of the UK referendum date to the implementation of Brexit, as periods of political uncertainty. Extant literature shows that the referendum outcome caused an increase in stock market volatility, both in the UK (Krause, Noth, \& Tonzer, 2016; Smales, 2017) and in German markets (Smales, 2017), similar to that registered around previous election days (Białkowski \& Gottschalk, 2006). Belke et al. (2018), extending the sample used by Smales (2017) to all European financial markets, demonstrate that the political uncertainty caused by Brexit affected European countries in different ways. In particular, Greece, Italy, Ireland, Portugal, and Spain (GIIPS) and the UK showed the strongest reactions to the referendum result. Campello, Cortes, d'Almeida, \& Kankanhalli (2018) investigate the relationship between Brexit and American firms, focusing on capital investments, employment growth, and R\&D expenditure. Their results show that US firms that were more exposed to the UK economy were the most affected by the referendum outcome. This suggests that political uncertainty can produce a contagion effect in other countries. In addition, Arshad, Rizvi, \& Haroon (2019) study market volatility during the Brexit period, distinguishing between pre- (7 May 2015 - 28 February 2016) and post-vote periods (March 2016 - May 2017). Their results show that the impact of the referendum outcome on market volatility differed between different UK sectors, and that the banking and technology sectors were the most affected industries. The authors explain the evidence on the increased volatility of bank shares by the high uncertainty regarding the future of the industry with EU countries. As suggested by Chung and Chuwonganant (2018), market volatility negatively affects stock returns both directly and indirectly through its impact on liquidity provision, and this negative relationship arises from greater risk and illiquidity premiums.

Government changes and the consequent political uncertainty can affect stock prices, as suggested by Pastor and Veronesi (2012) and Mei and Guo (2004). More specifically, political uncertainty seems to produce negative stock returns (Nippani \& Medlin, 2002; Santa-Clara \& Valcanov, 2003; Białkowski \& Gottschalk, 2008; He, Lin, Wu, \& Dufrene, 2009; Brogaard \& Detzel, 2015; Boutchkova, Doshi, Durnev, \& Molchanov, 2016).

The second strand of literature, which is recent and relatively underdeveloped, focuses on the impact of Brexit on stock prices (Schiereck et al., 2016; Oehler et al., 2017; Ramiah et al., 2017; Tielman \& Schiereck, 2017; Hill 
et al., 2019). Tielman and Schiereck (2017) concentrate specifically on the logistics sector. Their choice of sector is based on the assumption that this industry should be particularly affected by the referendum outcome, because of the potential slower movement of goods and increases in transport and freight costs. Their analysis shows that the announcement of the referendum outcome had a negative impact across the entire logistics sector in Europe, and especially in the UK. Diversified firms involved in road transportation appear to have suffered negative effects to a lower extent than specialised firms such as airlines. Oehler et al. (2017) investigate the role of internationalization, and demonstrate that more internationalized UK companies showed higher positive stock returns than firms characterized by more domestic sales. However, the positive effect of internationalization emerged only on the first trading day after the announcement of the referendum result. Hill et al. (2019) and Shahzad et al. (2019) confirm these results. All these findings suggest that firm-level internationalization is a diversification mechanism for coping with domestic risk.

To date, very few papers have specifically examined the effect of Brexit on the banking sector. In most of these studies, this sector is only one element in wider samples composed of multiple industries. However, the focus on the banking system is particularly important because investors are increasingly concerned about the ability of banks to withstand the consequences of Brexit (Chabot, Bertrand, \& Thorez, 2019).

Schiereck et al. (2016) compare Brexit with the Lehman Brothers crisis. They find that the former was not "another Lehman Brothers moment" for banks, for two reasons: first, the short-term drop in the bank stock market after the Lehman crisis was stronger than in the case of Brexit. Second, the increase in bank credit default swaps (CDS) spreads was significantly lower in the case of the UK referendum than in the case of the Lehman Brothers bankruptcy. On this point, Baur et al. (2018) remark that Brexit caused a storm, but no storm damage.

Ramiah et al. (2017), furthermore, analyse the effect of the announcement of the UK referendum result on various UK sectors over the period June-July 2016. They show that the event affected UK industries to different extents, and that the impact was particularly negative for the banking industry. Kadric and Korus (2019), considering both financial and non-financial sectors, investigate the effect of the referendum on risk conditions of the corporate bond market. They find that the spread of corporate bonds in the financial sector was influenced by the announcement of the result of the Brexit referendum, both in the UK and in the Eurozone. In non-financial sectors, only corporate bonds from the UK were influenced by the vote.

Finally, Aristeidis and Elias (2018), excluding the possible worldwide contagion effect of Brexit, find that share prices of the five largest British banks fell by an average of $21 \%$ in the morning after the announcement of the referendum result, and that stock prices in many other non-UK banks also fell by more than $10 \%$. This suggests that Brexit had a stronger impact on the banking sector than on other industries.

Previous literature about Brexit focuses on multiple industries, without investigating the specific role of the banking sector which, on the contrary, is particularly vulnerable to the consequences of the referendum. Moreover, extant studies investigate only the stock market effects of the referendum date and do not consider reactions to other important events related to Brexit. Furthermore, previous literature primarily focuses on the UK market, almost ignoring other European countries.

In this context, our research specifically focuses on the European banking sector, because this industry is probably the most exposed to the Brexit referendum outcome. The City of London has, in fact, long been the center of the European financial market, and its structure is likely to be influenced by political events related to Brexit. We specifically investigate the stock market reaction to different events, i.e. the announcements of the referendum date, the referendum result, and the day on which Theresa May became Prime Minister. The paper focuses on both the UK and the EU banking sectors, and seeks to identify and interpret the differences in the impact on these areas. Furthermore, the paper aims to investigate the possible firm characteristics that explain the bank stock market reactions to Brexit-related events.

\section{Sample and Methods}

\subsection{The Sample}

The sample consists overall of 213 listed banks: 46 from the UK and 167 from other European countries. Data were extracted from the Orbis database. Table 1 reports the distribution of banks among countries and the average value of the main bank-specific variables. These data suggest that UK banks show a higher profitability than EU banks: only Belgian and Finnish banks reach levels of return on assets similar to those of the UK. Moreover, we observe that banks with negative average profitability also show higher cost inefficiency (e.g. in Ireland, Hungary, and Croatia), and that the average capitalization is higher in UK and Belgium banks.

In order to avoid bias in the estimation of stock market performance, we exclude from our database all banks that 
announced price-relevant information from 10 days before to 10 days after our three "Days 0 ".

Table 1. Descriptive statistics by country

\begin{tabular}{llllll}
\hline Country & Number & Size & Profitability & Cost efficiency & Capitalization \\
\hline Uk & 46 & 14.445 & 4.202 & 69.269 & 54.479 \\
Austria & 4 & 18.129 & 0.643 & 59.303 & 8.466 \\
Belgium & 5 & 16.813 & 3.843 & 78.694 & 52.93 \\
Bulgaria & 2 & 15.332 & 0.200 & 38.440 & 8.44 \\
Cyprus & 2 & 15.098 & 0.830 & 49.600 & 12.560 \\
Croazia & 2 & 16.637 & -0.120 & 82.770 & 13.31 \\
Czechia & 1 & 17.311 & 1.420 & 44.740 & 11.920 \\
Denmark & 23 & 14.394 & 0.858 & 62.890 & 11.440 \\
Finland & 3 & 14.249 & 4.516 & 66.400 & 32.463 \\
France & 24 & 16.288 & 1.900 & 62.686 & 19.089 \\
Germany & 26 & 14.076 & 0.092 & 136.65 & 19.733 \\
Greece & 7 & 17.357 & -3.374 & 66.768 & 11.708 \\
Hungary & 2 & 16.018 & -0.405 & 94.025 & 13.040 \\
Ireland & 3 & 17.193 & -1.300 & 100.000 & 8.170 \\
Italy & 24 & 16.405 & 1.322 & 66.900 & 16.018 \\
Malta & 2 & 14.838 & 0.780 & 57.965 & 9.490 \\
Netherlands & 6 & 15.991 & 2.045 & 52.180 & 38.356 \\
Poland & 11 & 16.771 & 0.840 & 62.314 & 10.54 \\
Portugal & 2 & 17.826 & 0.695 & 59.6 & 7.275 \\
Romania & 5 & 13.645 & 2.812 & 71.938 & 41.656 \\
Spain & 8 & 18.593 & 0.511 & 59.767 & 6.787 \\
Sweden & 5 & 18.477 & 0.705 & 45.497 & 4.335 \\
\hline
\end{tabular}

Notes. Table 1 shows the average value of size (natural logarithm of total assets), profitability (the return on assets), cost efficiency (cost to income ratio) and capitalization (equity over total assets ratio) by country.

\subsection{Event Study Methodology}

The study investigates the impact of three different Brexit-related events on the stock prices of UK and European banks. Through an event study analysis (MacKinlay, 1997), we estimate the effect of the announcements of the referendum date (20 February 2016), the referendum result (23 June 2016), and the election of Theresa May as Prime Minister (11 July 2016).

The event study method is used to establish the abnormal returns of European banks, i.e. the difference between their counterfactual stock returns not affected by the information of the three events related to Brexit (expected returns) and their actual returns. This technique allows us to estimate the price effect arising from the three political events investigated.

Sharpe's (1963) market model was used to calculate expected stock returns:

$$
\hat{R}_{i, t}=\alpha_{i}+\beta_{i} R_{m k t, t}+\varepsilon_{i, t}
$$

Where $\widehat{\boldsymbol{R}}_{\boldsymbol{i}, \boldsymbol{t}}$ is the stock return of bank $i$ on day $t ; \alpha_{\mathrm{i}}$ is the intercept of the regression line; $\beta_{\mathrm{i}}$ is the slope of the regression line; $\mathrm{R}_{\mathrm{mk}, \mathrm{t}}$ is the national market index return on day $t$; and $\varepsilon_{\mathrm{i}, \mathrm{t}}$ is the random error.

Each of the three events related to Brexit is considered Day 0. The estimation period used for political events ranges from 280 days before Day 0 to 10 days before it. The $\alpha_{\mathrm{i}}$ and $\beta_{\mathrm{i}}$ coefficients are therefore estimated by OLS regressions of $\widehat{\boldsymbol{R}}_{i, t}$ on $\mathrm{R}_{\mathrm{mkt}}$ for 270 days. The wider event period ranges from 10 days before the political event to 10 days after it.

We calculate the abnormal return $\left(\mathrm{AR}_{\mathrm{i}, t}\right)$ due to each event for the bank $i$ on Day $t$ as follows:

$$
A R_{i, t}=R_{i, t}-\left(\hat{\alpha}_{i}+\hat{\beta}_{i} R_{m k t, t}\right)
$$

The average abnormal return $\left(\overline{\boldsymbol{A R}}_{\boldsymbol{t}}\right)$ is estimated as:

$$
\overline{A R}_{t}=\frac{1}{n} \sum_{i=1}^{n} A R_{i, t}
$$


Finally, the cumulative abnormal return $\boldsymbol{C A} \boldsymbol{R}_{\boldsymbol{i}}\left(\boldsymbol{\tau}_{\mathbf{1}}, \boldsymbol{\tau}_{\mathbf{2}}\right)$ for each stock $i$ is calculated by summing all $\mathrm{AR}_{\mathrm{i}, \mathrm{t}}$ within the event period $\left[\boldsymbol{\tau}_{1}, \boldsymbol{\tau}_{\mathbf{2}}\right]$ :

$$
C A R_{i}\left(\tau_{1}, \tau_{2}\right)=\sum_{t=\tau_{1}}^{\tau_{2}} A R_{i, t}
$$

While the mean cumulative abnormal returns (CARs) in the different event windows $\left(\overline{\boldsymbol{C A R}_{\boldsymbol{t}}}\left(\boldsymbol{\tau}_{\mathbf{1}}, \boldsymbol{\tau}_{\mathbf{2}}\right)\right)$ are estimated as follows:

$$
\overline{\operatorname{CAR}}_{i}\left(\tau_{1}, \tau_{2}\right)=\frac{1}{n} \sum_{i=1}^{n} C A R_{i}\left(\tau_{1}, \tau_{2}\right)
$$

In the event study analysis, we use an estimation window of 270 trading days, starting 280 trading days prior to our first event (20 February 2016) and ending 10 days before it. For subsequent announcements related to the referendum result (23 June 2016) and the election of Theresa May as Prime Minister (11 July 2016), we apply the same estimation window, where the start and end days are shifted for the specific dates. For the subsequent announcements, the moving estimation window includes prior events; therefore, we attempted to maintain the estimation window used for the event of 20 February 2016 as fixed for the subsequent events. Because the procedure had neither qualitative nor quantitative impacts on our results, we do not report in the paper these additional results, which are available on request.

To test the significance of the mean $(\overline{\boldsymbol{C A R}})$, we use two parametric and one non-parametric test.

Parametric tests use standardized abnormal returns to align event period abnormal returns' volatility with its estimation period volatility and to prevent stocks with high volatility from dominating test statistics (Boehmer et al., 1991). We calculate $T_{1}$, widely used in the previous literature (Campbell, Lo, \& MacKinley, 1997; MacKinlay, 1997), to test the null hypothesis that cumulative average abnormal returns are zero. It is constructed as follows:

$$
T_{1}=\frac{\overline{C A R}\left(\tau_{1}, \tau_{2}\right)}{\left[\widehat{\sigma}^{2}\left(\tau_{1}, \tau_{2}\right)\right]^{\frac{1}{2}}} \approx N(0,1)
$$

Because $T_{1}$ can be biased over a short time-period, we also estimate a second parametric test $\left(\mathrm{T}_{2}\right)$ that is more robust to an event-induced variance increase (Boehmer et al., 1991):

$$
T_{2}=\sqrt{N} \frac{\overline{\operatorname{SCAR}}\left(\tau_{1}, \tau_{2}\right)}{\sqrt{\frac{1}{N-1} \sum\left(\operatorname{SCAR}\left(\tau_{1}, \tau_{2}\right)-\overline{S C A R}\left(\tau_{1}, \tau_{2}\right)\right)^{2}}} \approx T\left(0, \frac{g}{g-2}\right)
$$

with $\mathrm{g}>2$, where $\mathrm{N}$ is the number of stocks and $\boldsymbol{S} \boldsymbol{C} \boldsymbol{A} \boldsymbol{R}_{\boldsymbol{i}}\left(\boldsymbol{\tau}_{\mathbf{1}}, \boldsymbol{\tau}_{\mathbf{2}}\right)$ is the standardized abnormal return on security $i$ at day $t$. We follow the methodology suggested by Mikkelson and Partch (1988) in order to estimate $\boldsymbol{S C A R}_{\boldsymbol{i}}\left(\boldsymbol{\tau}_{\mathbf{1}}, \boldsymbol{\tau}_{\mathbf{2}}\right)$ :

$$
S C A R_{i, t}=\frac{\operatorname{CAR}_{i}\left(\tau_{1}, \tau_{2}\right)}{\widehat{\sigma_{l}} \sqrt{T_{S}+\frac{T_{S}^{2}}{T}+\frac{\sum_{i=\tau_{1}}^{\tau_{2}}\left(R_{m, t}-T_{S} \overline{R_{m}}\right)}{\sum_{i=1}^{T}\left(R_{m, t}-\overline{R_{m}}\right)}}}
$$

where $\tau_{1}$ and $\tau_{2}$ are respectively the first and last days in the event window, $\boldsymbol{C A R}_{\boldsymbol{i}}\left(\boldsymbol{\tau}_{1}, \boldsymbol{\tau}_{\mathbf{2}}\right)$ is the cumulative abnormal return of stock $i$ in the event window $\left(\boldsymbol{\tau}_{\mathbf{1}}, \boldsymbol{\tau}_{\mathbf{2}}\right), \overline{\boldsymbol{R}_{\boldsymbol{m}}}$ is the mean return on market index in the estimation period, $\widehat{\boldsymbol{\sigma}}_{\boldsymbol{\imath}}$ is the estimated standard deviation of abnormal return on stock $i, \mathrm{~T}$ is the number of days in the estimation period, and $\mathrm{T}_{\mathrm{s}}$ is the number of days in the event window. $\mathrm{T}_{2}$ shows a $\mathrm{T}$-distribution with $\mathrm{T}-2$ degrees of freedom, and converges to a unit normal. In order to confirm the results obtained by $\mathrm{T}_{1}$ and $\mathrm{T}_{2}$, we also perform the non-parametric test suggested by Campbell et al. (1997) and MacKinlay (1997):

$$
T_{3}=\left[\frac{N^{(+/-)}}{N}-0.5\right] \frac{N^{\frac{1}{2}}}{0.5} \approx N(0,1)
$$

Where $\mathrm{N}$ is the number of events and $\mathrm{N}(+) / \mathrm{N}(-)$ is the number of events with a positive/negative CAR. We consider statistically significant CARs as those that passed all the three tests described above.

\subsection{The Regression Model}

In the second stage of our empirical analysis, we run OLS regressions with robust standard errors to investigate determinants of CARs. Our models are constructed as follows:

$$
\begin{gathered}
y_{i}=\alpha+\beta_{1} X_{i, \mathrm{t}}+\varepsilon_{i} \quad i=1, \ldots, N \\
y_{i}=\alpha+\beta_{1} X_{i, \mathrm{t}}+\beta_{2} \text { GIIPS }_{\mathrm{i}, \mathrm{j}}+\beta_{3} \text { EAST_COUNTRIES }_{\mathrm{i}, \mathrm{j}}+\varepsilon_{i} \quad i=1, \ldots, N
\end{gathered}
$$


Regression (10) is run on the subsample of UK banks, while regression (11) is run on the subsample of other European banks. In both regressions, subscript $i$ denotes the cross-section dimension, and $t$ and $j$ the time and the country of the country-specific variable, respectively. We use the statistically significant CARs observed in the previous event study analysis as the dependent variable. The $\mathrm{X}$ vector refers to the bank-specific characteristics in terms of balance sheet ratios.

With regard to the $\mathrm{X}$ vector, we consider the following bank-specific characteristics: i) the equity over total assets ratio (E_TA) as the measure of capitalization; ii) the return on asset (ROA) as the measure of profitability; iii) the cost-to-income ratio (COST_INCOME) as the measure of bank cost efficiency; iv) and, finally, the natural logarithm of total assets (SIZE) as the measure of bank size.

In regression (11), we also include two dummy-country variables: i) GIIPS equals 1 when the bank is located in Greece, Italy, Portugal, Spain, or Ireland, and 0 otherwise; ii) EAST_COUNTRIES equals 1 when the bank is located in Bulgaria, Croatia, Poland, Czech Republic, Romania, or Hungary, and 0 otherwise. We introduce GIIPS and EAST_COUNTRIES into the model in order to identify differences between European geographical areas. Specifically, the first dummy identifies banks operating in the countries that were most affected by the financial and the sovereign debt crises of 2008 and 2011 and, for this reason, are characterized by a quite fragile banking sector. The second dummy variable refers to banks operating in Eastern European countries, i.e. banks that belong to the EU, but not to the Eurozone, excluding Denmark and Sweden (Note 3).

Descriptive statistics and the t-test on means and correlations are presented in Table 2 and Table 3 , respectively. The null hypothesis of the difference in means test is that the two means of the two group are equal. Our results show the difference in means of our two subsamples (UK banks and EU banks) is always statistically significant, except for the cost-to-income ratio. All banks show, in general, a positive profitability and a good level of capitalization and cost efficiency. Compared with other EU banks, UK banks are larger and characterized by higher cost efficiency, lower profitability, and lower capitalization.

We consider three different events related to Brexit. For each event, we test the regression models (10) and (11) on the event windows showing statistical significance in the event study analysis.

Table 2. The descriptive statistics

\begin{tabular}{|c|c|c|c|c|c|c|c|c|c|c|c|c|}
\hline \multirow[b]{2}{*}{ Variable } & \multicolumn{5}{|c|}{ TOTAL SAMPLE } & \multicolumn{3}{|c|}{ UK BANKS } & \multicolumn{3}{|c|}{ EU BANKS } & \multirow[b]{2}{*}{ T-test } \\
\hline & Obs & Mean & Std. Dev. & Min & $\operatorname{Max}$ & Obs & Mean & Std. Dev. & Obs & Mean & Std. Dev. & \\
\hline SIZE & 197 & 15.540 & 2.849 & 7.869 & 21.517 & 45 & 14.445 & 3.037 & 155 & 15.859 & 2.721 & $* * *$ \\
\hline E_TA & 197 & 25.951 & 31.474 & -79.09 & 99.63 & 45 & 54.479 & 36.028 & 155 & 17.669 & 24.544 & $* * *$ \\
\hline $\mathrm{ROA}$ & 197 & 1.702 & 6.855 & -46.27 & 25.43 & 45 & 4.202 & 11.138 & 155 & 0.977 & 4.789 & $* * *$ \\
\hline $\begin{array}{l}\mathrm{COST}_{-} \\
\text {INCOME }\end{array}$ & 197 & 73.749 & 10.834 & -29.56 & 133.455 & 45 & 69.270 & 11.964 & 155 & 75.058 & 10.520 & \\
\hline
\end{tabular}

Notes. The Table reports the descriptive statistics of bank specific characteristics for the total sample and for the subsamples of UK and EU banks. Size is the natural logarithm of total assets, E_TA is the equity over total assets ratio as proxy of bank capitalization, ROA is the return on assets as proxy of bank profitability and COST_INCOME is the cost to income ratio as proxy of bank cost efficiency. In the last column, the significance of the T-test of means is reported. ${ }^{*},{ }^{* *},{ }^{* * *}$ denote the statistical significance at $10 \%, 5 \%$ and $1 \%$, respectively.

Table 3. The correlation matrix

\begin{tabular}{lllll}
\hline & SIZE & E_TA & ROA & COST_INCOME \\
\hline SIZE & 1 & & & \\
E_TA & -0.5263 & 1 & & \\
ROA & -0.1018 & 0.4237 & 1 & \\
COST_INCOME & -0.1827 & -0.1863 & -0.5217 & 1 \\
\hline
\end{tabular}

Notes. The Table reports the correlation matrix of bank specific characteristics. Size is the natural logarithm of total assets, E_TA is the equity over total assets ratio as proxy of bank capitalization, ROA is the return on assets as proxy of bank profitability and COST_INCOME is the cost to income ratio as proxy of bank cost efficiency. 


\section{Results}

\subsection{Event Study}

We investigate, through an event study analysis, the stock price reactions of UK and other European listed banks to three different events related to Brexit: the announcements of the referendum date, the referendum result, and the election of Theresa May as Prime Minister.

The first event we consider is the announcement (on 20 February 2016) of the referendum date. Table 4 shows the event study results we record for this date.

Table 4. The referendum announcement: the effect on UK and other European banks

\begin{tabular}{|c|c|c|c|c|c|c|c|c|c|c|}
\hline \multirow[b]{2}{*}{$\begin{array}{l}\text { Event } \\
\text { window }\end{array}$} & \multicolumn{5}{|l|}{$\begin{array}{l}\text { Panel A) } \\
\text { UK banks }\end{array}$} & \multicolumn{5}{|c|}{$\begin{array}{l}\text { Panel B) } \\
\text { Other European banks }\end{array}$} \\
\hline & Mean CAR & $\begin{array}{l}\text { Number of } \\
\text { firms }\end{array}$ & $\mathrm{T}_{1}$ & $\mathrm{~T}_{2}$ & $\mathrm{~T}_{3}$ & Mean CAR & $\begin{array}{l}\text { Number } \\
\text { of firms }\end{array}$ & $\mathrm{T}_{1}$ & $\mathrm{~T}_{2}$ & $\mathrm{~T}_{3}$ \\
\hline$(-10,-1)$ & $0.052^{* * *}$ & 45 & 4.101 & 4.774 & 4.919 & $0.050^{* *}$ & 164 & 5.393 & 1.966 & 4.998 \\
\hline$(-5,-1)$ & $0.058^{* * *}$ & 45 & 7.461 & 9.433 & 6.112 & $0.068^{* * *}$ & 164 & 10.106 & 3.910 & 8.746 \\
\hline$(-3,-1)$ & $0.036^{* *}$ & 45 & 6.175 & 1.927 & 5.516 & $0.019^{* * *}$ & 164 & 6.561 & 2.446 & 5.622 \\
\hline$(-1,0)$ & $0.024^{* * *}$ & 45 & 6.346 & 2.343 & 5.218 & $0.020^{* * *}$ & 164 & 6.405 & 2.593 & 7.028 \\
\hline$(0,10)$ & $0.090^{* *}$ & 45 & 7.960 & 2.148 & 4.919 & $0.150^{* * *}$ & 164 & 9.109 & 14.200 & 9.370 \\
\hline$(0,5)$ & $0.059^{* * *}$ & 45 & 7.279 & 2.671 & 5.218 & $0.094^{* * *}$ & 164 & 8.171 & 3.807 & 8.277 \\
\hline$(0,3)$ & $0.043^{* *}$ & 45 & 6.879 & 2.266 & 5.218 & $0.056^{* * *}$ & 164 & 7.831 & 3.783 & 7.653 \\
\hline$(0,1)$ & $0.028^{* * *}$ & 45 & 6.141 & 2.967 & 4.919 & $0.046^{* *}$ & 164 & 7.433 & 1.928 & 7.965 \\
\hline
\end{tabular}

Notes. Table 4 shows the results of event studies carried out on UK and European banks related to the announcement of the referendum date (on 20 February 2016). We measured the predicted normal bank returns using the market model. The CAR statistical significance is verified using three tests $\left(\mathrm{T}_{1}, \mathrm{~T}_{2}\right.$ and $\mathrm{T}_{3}$ ) reported in Equations (6), (7) and (9). ${ }^{*},{ }^{* *},{ }^{* * *}$ denote the statistical significance at $10 \%, 5 \%$ and $1 \%$, respectively (one-tailed test).

Our results show positive and statistically significant mean CARs in all the investigated event windows.

Focusing on UK banks (Table 4, Panel A), we identify statistically significant mean CARs both before and after Day 0. More specifically, we estimate mean CARs equal to $5.2 \%, 5.8 \%, 3.6 \%$, and $2.4 \%$ in the event windows $(-10$, $-1),(-5,-1),(-3,-1)$, and $(-1,0)$ respectively. This means that the news of the referendum date was probably circulating some days before its official announcement, and that the UK banks positively priced this information. A positive reaction was also registered after Day 0 , because we find statistically significant mean CARs equal to $2.8 \%, 4.3 \%, 5.9 \%$, and $9 \%$ in the event windows $(0,1),(0,3),(0,5)$, and $(0,10)$, respectively.

These positive results, both before and after the event date, can be explained by considering that, in February 2016, UK bank shareholders did not consider the referendum outcome as an uncertain event, as suggested by Pantzalis et al. (2000), Goodel and Vähämaa (2013), Brogaard and Detzel (2015), and Smales (2015, 2016). They believed that "remain" would win, and that this scenario would guarantee stability to the UK. This interpretation is supported by the strong "pro-remain" position taken by the Prime Minister David Cameron, who was, at that time, very credible. In his Downing Street statement after the Cabinet meeting on 20 February 2016, Cameron in fact stated "...Leaving Europe would threaten our economic and our national security. Those who want to leave Europe cannot tell you if British businesses would be able to access Europe's free trade single market or if working people's jobs are safe or how much prices would rise. All they are offering is risk at a time of uncertainty - a leap in the dark. Our plan for Europe gives us the best of both worlds...". Moreover, during that period, "remain" received higher volumes of coverage than "leave" across most UK economic publications, as reported by Moore and Ramsay (2017), and this supported the widespread view that "remain" was the most likely outcome of the referendum.

We also study the impact of the announcement of the referendum date on the stock prices of other European banks. Our results (Table 4, Panel B) show positive and statistically significant mean CARs in all the investigated event windows, both before and after the event date. This result can be interpreted as evidence that European bank shareholders also considered "remain" as the most likely outcome of the referendum. They believed that this 
scenario would have guaranteed stability not only to the UK, but to all other European countries and, consequently, the market positively priced the information on the call for the referendum.

Figure 1 compares the reaction to the announcements of the referendum date between UK and other European bank shareholders.

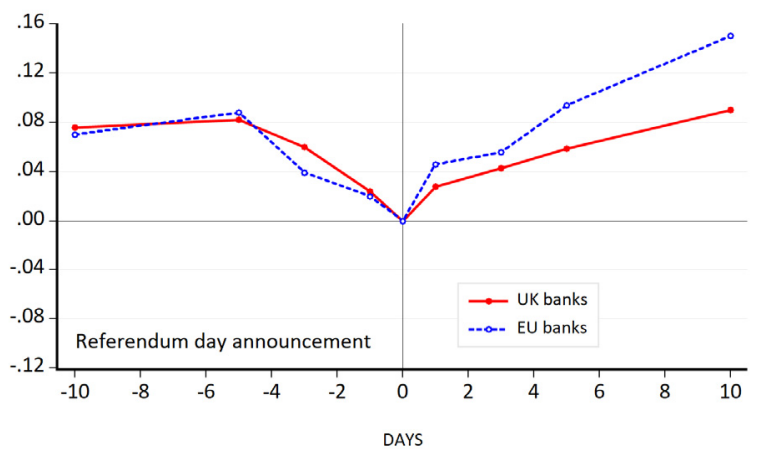

Figure 1. The referendum announcement: reactions of UK and other European bank shareholders

Notes. Figure 1 shows the results of event studies carried out on UK and European banks related to the announcement of the referendum date (on 20 February 2016). The Figure displays cumulative abnormal returns from day [-10] to day [+10] around the event date.

It shows that, in all UE, the news of the referendum date circulated some days before its official announcement and that, during this period, this information was positively and almost equally priced by UK and other European banks. This can be explained by considering that 20 February represents the conclusion of a period of waiting, that started in 2013, for the Brexit referendum to be announced, in accordance with the commitment of David Cameron, who had been re-elected as the UK Prime Minister on 7 May 2015, to hold a vote for the UK to remain in or leave the EU. In this context, the announcement of a specific date for this vote was perceived as a positive event by financial markets because, after several periods of discussion, Cameron kept his promise regarding the referendum.

Although the information about the official announcement of the referendum date was positively priced by all European bank shareholders, the reaction of other European countries was stronger than in the UK, as shown in Figure 1. This might have been because of the content of Cameron's speech on 20 February 2016. His speech was in fact not only pro-remain, but significantly Europeanist, as he stated "...I believe we will be safer in a reformed Europe, because we can work with our European partners to fight cross border crime and terrorism. I believe Britain will be stronger in a reformed Europe because we can play a leading role in one of the world's largest organizations from within, helping to make the big decisions on trade and security that determine our future. And I believe we will be better off in a reformed Europe because British businesses will have full access to the free trade single market, bringing jobs, investment and lower prices....". Cameron's message therefore emphasized the benefits to the UK if "remain" had prevailed over "leave": in a context in which this outcome seemed rather obvious, this may explain, in our opinion, the more positive reaction of other European bank shareholders compared with that of bank shareholders in the UK.

The second event we consider is the actual referendum vote, which took place on 23 June 2016. Table 5 shows the results of the event study analysis. 
Table 5. The referendum vote: the effect on UK and other European listed banks

\begin{tabular}{|c|c|c|c|c|c|c|c|c|c|c|}
\hline & $\begin{array}{l}\text { Panel A) } \\
\text { UK banks }\end{array}$ & & & & & $\begin{array}{l}\text { Panel B) } \\
\text { Other Euror }\end{array}$ & $n$ banks & & & \\
\hline $\begin{array}{l}\text { Event } \\
\text { window }\end{array}$ & Mean CAR & $\begin{array}{l}\text { Number of } \\
\text { firms }\end{array}$ & $\mathrm{T}_{1}$ & $\mathrm{~T}_{2}$ & $\mathrm{~T}_{3}$ & Mean CAR & $\begin{array}{l}\text { Number } \\
\text { of firms }\end{array}$ & $\mathrm{T}_{1}$ & $\mathrm{~T}_{2}$ & $\mathrm{~T}_{3}$ \\
\hline$(-10,-1)$ & -0.002 & 46 & -0.341 & -1.300 & 3.833 & -0.009 & 167 & -1.831 & -0.490 & 0.232 \\
\hline$(-5,-1)$ & $0.040^{* * *}$ & 46 & 5.730 & 2.997 & 4.128 & $0.039^{* * *}$ & 167 & 7.796 & 5.259 & 7.042 \\
\hline$(-3,-1)$ & $0.034^{* *}$ & 46 & 6.735 & 1.783 & 4.128 & $0.028^{* * *}$ & 167 & 8.661 & 3.234 & 8.125 \\
\hline$(-1,0)$ & $0.017^{* *}$ & 46 & 6.215 & 3.223 & 4.718 & $0.020^{* * *}$ & 167 & 6.581 & 6.461 & 5.649 \\
\hline$(0,10)$ & $-0.074^{* *}$ & 46 & -3.292 & -1.793 & 1.769 & $-0.060^{* *}$ & 167 & -5.797 & -2.212 & 5.494 \\
\hline$(0,5)$ & $-0.063^{* *}$ & 46 & -3.772 & -2.001 & 2.654 & $-0.039^{* *}$ & 167 & -5.072 & -1.963 & 4.720 \\
\hline$(0,3)$ & $-0.092^{* * *}$ & 46 & -5.298 & -6.105 & 5.308 & $-0.049^{* * *}$ & 167 & -6.828 & -4.890 & 6.113 \\
\hline$(0,1)$ & -0.043 & 46 & -4.939 & 1.061 & 3.833 & $-0.037^{* *}$ & 166 & -5.437 & 1.996 & 6.209 \\
\hline
\end{tabular}

Notes. Table 5 shows the results of event studies carried out on UK and European banks related to referendum vote (on 23 June 2016 ). We measured the predicted normal bank returns using the market model. The CAR statistical significance is verified using three tests $\left(\mathrm{T}_{1}\right.$, $\mathrm{T}_{2}$ and $\mathrm{T}_{3}$ ) reported in Equations (6), (7) and (9). ${ }^{*},{ }^{* *},{ }^{* * *}$ denote the statistical significance at $10 \%, 5 \%$ and $1 \%$, respectively (one-tailed test).

Our results show that UK and other European bank shareholders had a similar reaction to the referendum outcome. More specifically, before Day 0, our findings show positive and statistically significant mean CARs in the event windows $(-5,-1),(-3,-1)$, and $(-1,0)$ equal to $4 \%, 3.4 \%$, and $1.7 \%$ for UK banks, and equal to $3.9 \%, 2.8 \%$, and $2 \%$ for other European banks, respectively. Figure 2 compares the reaction to the announcements of the referendum outcome of UK and other European bank shareholders.

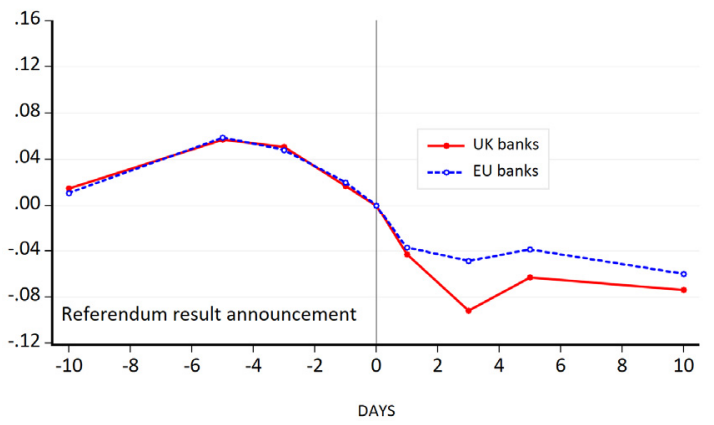

Figure 2. The referendum vote: reactions of UK and other European bank shareholders

Notes. Figure 2 shows the results of event studies carried out on UK and European banks related to the referendum vote (on 23 June 2016 ). The Figure displays cumulative abnormal returns from day [-10] to day [+10] around the event date.

This suggests that, in the days before 23 June 2016, bank shareholders positively priced information on the referendum vote, because "remain" was considered the most likely outcome. On 23 June, the largest UK betting agencies expected the "remain" camp to prevail: the bookmakers' odds indicated a $90 \%$ chance that the UK would still remain in the EU after the referendum had been concluded (Bloomberg, 2016). For example, the well-known agency Paddy Power had the odds for remain at 1/12, while the payoff for exit was 7/1 (Davies \& Studnicka, 2018) (Note 4). The exchange rate and financial market dynamics also confirm our interpretation. On 23 June 2016, the sterling in fact reached its 2016 high of $\$ 1.5018$ and the FTSE 100 climbed to a 2016 high, as the most believable exit-pool announced a vote for "remain".

However, the actual referendum outcome completely surprised the market: initial results suggested that "remain" was going to win, and when the Sunderland results were declared, the swing to "leave" was entirely unexpected (Davies \& Studnicka, 2018).

In this context, our results show that UK and other European bank shareholders reacted negatively to the referendum outcome. More specifically, after Day 0, we estimate negative and statistically significant mean CARs in the event windows $(0,3),(0,5)$, and $(0,10)$ equal to $-9.2 \%,-6.3 \%$, and $-7.4 \%$ for UK banks and equal to $-4.9 \%$, 
$-3.9 \%$, and $-6 \%$ for other European banks, respectively. This can be interpreted as evidence that, in the days after 23 June 2016, all European bank shareholders negatively priced the information on the referendum outcome. The negative reaction can be explained considering that the Brexit result was unexpected, and, for this reason, it triggered significant political uncertainty, as suggested by Pantzalis, Stangeland, \& Turtle (2000) and Brogaard and Detzel (2015). The UK is in fact the world's largest exporter of financial services and approximately one-third of these exports are to the EU. Hence, the decision of the UK to leave the EU triggered widespread concern for the future of the financial sector, both in the UK and in the EU, as suggested by Howarth and Quaglia (2018). From the perspective of the UK, firms found that it would be considerably more expensive to export to the EU in an unexpected Brexit scenario. From the EU perspective, Brexit was likely to cause losses to the EU27 which, being over-reliant on banking, used many UK specialized capital markets services (Armour, 2017). It was often argued that Brexit would not only damage the UK banking sector, but also impair the financing of the entire European economy.

Our evidence on bank stock returns following the referendum outcome are supported by data for the same period for the exchange rate and FTSE 100. Following the announcement of the referendum outcome, the sterling in fact fell immediately to its lowest level since 1985 and, on the morning of 24 June 2016, the FTSE 100 fell from 6338.10 to 5806.13 in the first ten minutes of trading.

The information about the outcome of the referendum date was therefore negatively priced by all European bank shareholders, but the reaction in the UK was stronger than in the other European countries, as shown in Figure 2. This can be explained considering that the City of London has been Europe's leading financial center for decades. Brexit potentially posed a great threat to this position, because of the possibility that many international banks, as well as the European Banking Authority (EBA), would move their offices elsewhere (in fact, the EBA moved to Paris in March 2019). Moreover, on 24 June 2016, based on the result of the referendum, Moody's downgraded the UK's debt rating outlook from "stable" to "negative", and both Standard \& Poor's and Fitch Ratings lowered the UK's rating to AA. Furthermore, following the vote, the International Monetary Fund (IMF) forecasted a decrease in global economic growth by $0.1 \%$, and even greater reductions in the UK. The UK's downgrading and pessimistic IMF forecasts for the UK therefore offer additional explanation for the higher negative reaction to the referendum outcome by UK bank's shareholders compared to the European banks' shareholders.

The election of Theresa May as Prime Minister, which took place on 11 July 2016, is the third event that we investigate. The results of our event study analysis are shown in Table 6.

Table 6. The election of Theresa May: the effect on UK and other European listed banks

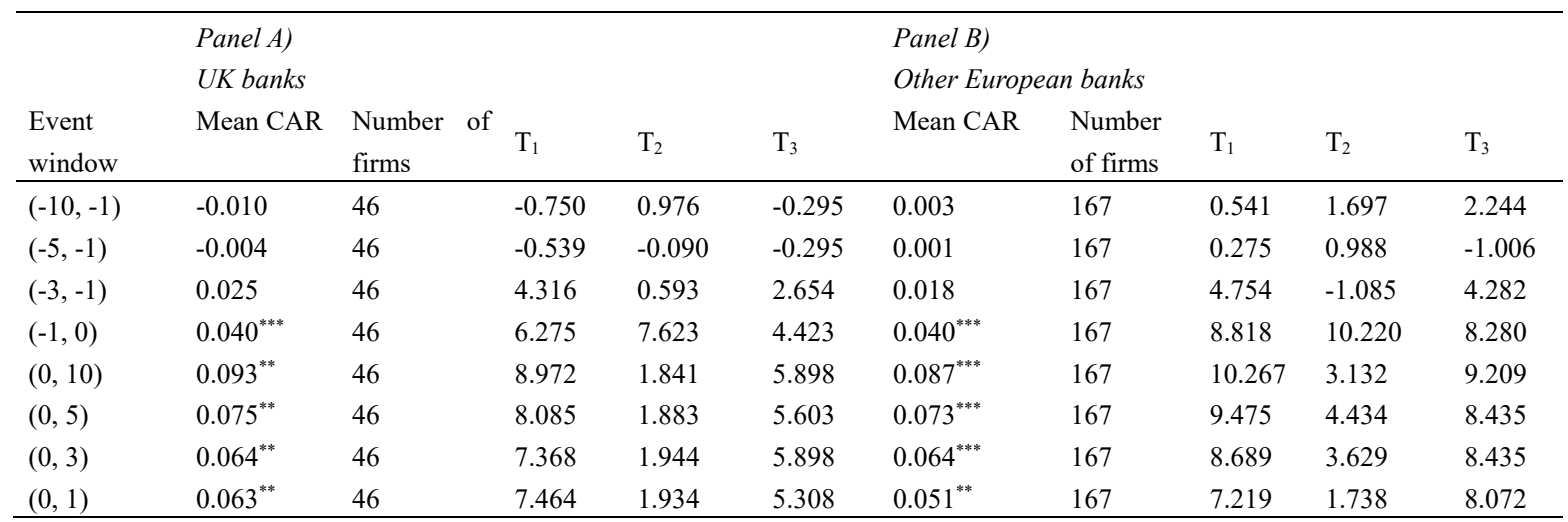

Notes. Table 6 shows the results of event studies carried out on UK and European banks related to the election of Theresa May (on 11 July 2016). We measured the predicted normal bank returns using the market model. The CAR statistical significance is verified using three tests $\left(\mathrm{T}_{1}, \mathrm{~T}_{2}\right.$ and $\mathrm{T}_{3}$ ) reported in Equations (6), (7) and (9). ${ }^{*},{ }^{* *},{ }^{* * *}$ denote the statistical significance at $10 \%, 5 \%$ and $1 \%$, respectively (one-tailed test).

Our results show that, in this case too, UK and other European bank shareholders had the same reaction to the event, as shown in Figure 3. 


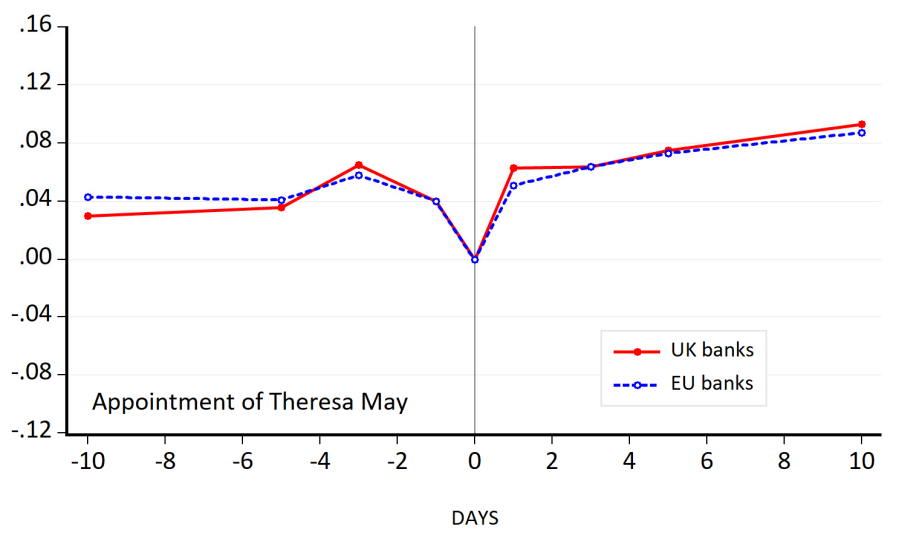

Figure 3. The election of Theresa May: reactions of UK and other European bank shareholders

Notes. Figure 3 shows the results of event studies carried out on UK and European banks related the election of Theresa May (on 11 July 2016). The Figure displays cumulative abnormal returns from day [-10] to day $[+10]$ around the event date.

We find, in fact, positive and statistically significant mean CARs in the event windows $(-1,0),(0,1),(0,3),(0,5)$, and $(0,10)$ equal to $4 \%, 6.3 \%, 6.4 \%, 7.5 \%$, and $9.3 \%$ for UK banks, and equal to $4 \%, 5.1 \%, 6.4 \%, 7.3 \%$, and $8.7 \%$ for other European banks, respectively.

These findings can be interpreted as evidence that the election of Theresa May was perceived as "good news" by bank shareholders, both in the UK and other European countries.

The new Prime Minister Theresa May emerged in the UK as the "unity candidate" to succeed David Cameron. She carefully cultivated an image of political dependability and unflappability that made her appear to be the "right person at the right time", and she was widely perceived to be a trustworthy and credible politician. On 11 July 2016 , she immediately promised to build a "better Britain" and to make the UK's EU exit a "success". In this context, the election of Theresa May as Prime Minister allowed UK bank shareholders to immediately assess the effect on the country's future. This probably explains the positive stock returns calculated for Britain, as suggested by Pantzalis et al. (2000), Goodel and Vähämaa (2013), Brogaard and Detzel (2015), and Smales (2015, 2016). It is not by chance that, after the election of Theresa May as Prime Minister, larger UK banks, such as Lloyds TSB, HSBC and Barclays, announced 'contingency plans' to move staff and operations to the EU27 in the event that Brexit negotiations did not ensure full access to the Single Market.

In other European countries, when the election of Theresa May as Prime Minister made the Brexit scenario more certain, bank shareholders identified opportunities for the Euro-area to attract potential financial business from London, as suggested by Howarth and Quaglia (2018): for example, many US banks that used the UK as a point of entry into the Single Market, through UK-based subsidiaries, announced plans to open offices in Frankfurt. These new opportunities could explain the positive reaction registered in the days after 11 July 2016 by other European bank stock returns.

The event study analyses allowed us to answer our first two research questions.

The news about the referendum date, when "remain" was globally considered as the most likely outcome, circulated some days before 20 February 2016. It was positively and almost equally priced by UK and other European banks before its official announcement, whereas after the event, the positive reaction in other European countries was stronger than in the UK. Moreover, in the days before 23 June 2016, all European bank shareholders positively priced information on the referendum vote, because "remain" was still considered the most likely outcome. However, the Brexit result completely surprised the market. This news was therefore negatively priced by all European bank shareholders, especially in the UK. Furthermore, the election of Theresa May as Prime Minister, which took place on 11 July 2016, was considered "good information". UK and other European bank shareholders in fact had the same positive reaction to the news, because Theresa May was described by the press and, consequently, perceived by investors, as a true leader, and a credible individual, who promised to build a "better Britain" and to make the UK's EU exit a "success".

\subsection{Econometric Results}

To investigate the determinants of significant CARs quantified in the three event dates related to Brexit, we run some cross-sectional regressions. We use two subsamples: i) banks operating in the EU, excluding the UK; and ii) 
UK banks. We run some regressions on CARs estimated in the event windows showing the highest significance in the event study analysis.

First, we focus on 20 February 2016, the day on which Cameron announced the referendum date. Our results, both for European (Table 7a) and UK (Table 7b) banks show that, among the firm-specific variables, size, cost efficiency, and profitability contribute to explaining the CARs. However, only the positive coefficient of size and ROA, in some event windows, display a magnitude worthy of consideration. This means that, on 20 February 2016, the shareholders of the larger European and UK banks reacted very positively to the announcement of the referendum date. This evidence could be explained considering that, in a context in which the "remain" outcome seemed rather obvious, larger banks were likely to gain the highest benefits from the strongest and reformed Europe that Cameron described. Looking at the bank profitability, our results show a negative relationship between ROA and CAR in the event windows (EW) after the announcement of the referendum date. In particular, with regard to the EW $(0,+10)$, if ROA increases of $1 \%$, the CAR decreases of $1.1 \%$, while in the case of EW $(0,+5)$, CAR decreases of $0.7 \%$, suggesting that banks with higher profitability are less impacted by the Brexit referendum date announcement.

Among the country variables (Table 7a), EAST_COUNTRIES does not contribute to explaining the CARs, while the coefficients of GIIPS are statistically significant and show high magnitudes in every time window. This suggests that shareholders of banks operating in Greece, Italy, Portugal, Spain, and Ireland had the strongest positive reaction to the announcement of the referendum date, indicating that banks characterized by high sector fragility following the financial and the sovereign debt crises of 2008 and 2011, were considered to gain the strongest advantages from the reformed Europe that Cameron imagined.

Table 7a. Regression analysis: investor reaction to the referendum announcement (EU banks)

\begin{tabular}{lllllllll}
\hline VARIABLES & CAR(-10,-1) & CAR(-5,-1) & CAR(-3,-1) & CAR(-1,0) & CAR $(0,+10)$ & CAR $(0,+5)$ & CAR $(0,+3)$ & CAR $(0,+1)$ \\
\hline Constant & -0.073 & -0.057 & -0.007 & $-0.058^{* * *}$ & $-0.181^{*}$ & $-0.126^{* *}$ & -0.053 & $-0.082^{* *}$ \\
& $(0.06)$ & $(0.04)$ & $(0.02)$ & $(0.02)$ & $(0.09)$ & $(0.06)$ & $(0.04)$ & $(0.03)$ \\
E_TA & -0.000 & 0.000 & -0.001 & 0.001 & 0.001 & 0.001 & -0.001 & 0.000 \\
& $(0.00)$ & $(0.00)$ & $(0.00)$ & $(0.00)$ & $(0.00)$ & $(0.00)$ & $(0.00)$ & $(0.00)$ \\
ROA & 0.002 & -0.001 & $0.002^{* *}$ & 0.001 & $-0.011^{* *}$ & $-0.007^{* *}$ & -0.001 & -0.001 \\
& $(0.00)$ & $(0.00)$ & $(0.001)$ & $(0.00)$ & $(0.00)$ & $(0.00)$ & $(0.00)$ & $(0.00)$ \\
COST_INCOME & -0.000 & 0.000 & 0.000 & $0.001^{* * *}$ & $0.001^{* * *}$ & $0.001^{* * *}$ & $0.001^{* * *}$ & $0.001^{* * *}$ \\
& $(0.00)$ & $(0.00)$ & $(0.00)$ & $(0.00)$ & $(0.00)$ & $(0.00)$ & $(0.00)$ & $(0.00)$ \\
SIZE & $0.006^{*}$ & $0.005^{* *}$ & 0.001 & $0.003^{* * *}$ & $0.013^{* * *}$ & $0.008^{* *}$ & 0.003 & $0.005^{* * *}$ \\
& $(0.00)$ & $(0.00)$ & $(0.00)$ & $(0.00)$ & $(0.00)$ & $(0.00)$ & $(0.00)$ & $(0.00)$ \\
GIIPS & $0.098^{* * *}$ & $0.076^{* * *}$ & $0.012^{*}$ & $0.015^{* * *}$ & $0.219^{* * *}$ & $0.137^{* * *}$ & $0.067^{* * *}$ & $0.051^{* * *}$ \\
& $(0.01)$ & $(0.01)$ & $(0.00)$ & $(0.00)$ & $(0.02)$ & $(0.01)$ & $(0.01)$ & $(0.00)$ \\
EAST_COUNTRIES & 0.025 & 0.004 & 0.009 & -0.009 & -0.007 & -0.022 & -0.017 & -0.013 \\
& $(0.02)$ & $(0.01)$ & $(0.01)$ & $(0.00)$ & $(0.03)$ & $(0.02)$ & $(0.01)$ & $(0.01)$ \\
Observations & 152 & 152 & 152 & 152 & 152 & 152 & 152 & 152 \\
R-squared & 0.259 & 0.282 & 0.060 & 0.475 & 0.597 & 0.645 & 0.533 & 0.625 \\
\hline
\end{tabular}

Notes. Table $7 \mathrm{a}$ shows the results of the regression model run on CARs estimated around the announcement of the referendum date (20 February 2016). The dependent variables are CARs quantified in the event windows showing the highest significance in the event study analysis for subsamples of EU banks. Bank-specific variables are the following: equity over total assets (E_TA) as measure of capitalization, ROA as measure of profitability, the COST_INCOME ratio as proxy of bank cost efficiency, the natural logarithm of total revenues (SIZE) as proxy of firm size; GIIPS is a dummy variable equals 1 when bank is placed in Greece, Italy, Portugal, Spain or Ireland, 0 otherwise; EAST_COUNTRIES is a dummy variable equals 1 when bank is placed in Bulgaria, Croatia, Poland, Czech Republic, Romania and Hungary, and 0 otherwise. ${ }^{*},{ }^{* *},{ }^{* * *}$ denote the statistical significance at $10 \%, 5 \%$ and $1 \%$ level, respectively. 
Table 7b. Regression analysis: investor reaction to the referendum announcement (UK banks)

\begin{tabular}{lllllllll}
\hline VARIABLES & CAR(-10,-1) & CAR $(-5,-1)$ & CAR $(-3,-1)$ & CAR $(-1,0)$ & CAR $(0,+10)$ & CAR $(0,+5)$ & CAR $(0,+3)$ & CAR $(0,+1)$ \\
\hline Constant & $0.185^{* *}$ & 0.062 & 0.049 & 0.031 & -0.101 & -0.046 & -0.032 & 0.012 \\
& $(0.07)$ & $(0.05)$ & $(0.03)$ & $(0.02)$ & $(0.08)$ & $(0.06)$ & $(0.04)$ & $(0.03)$ \\
E_TA & -0.001 & $-4.57 \mathrm{e}-05$ & $7.12 \mathrm{e}-05$ & 0.001 & 0.001 & 0.001 & 0.001 & 0.001 \\
& $(0.00)$ & $(0.00)$ & $(0.00)$ & $(0.00)$ & $(0.00)$ & $(0.00)$ & $(0.00)$ & $(0.00)$ \\
\multirow{2}{*}{ ROA } & $-0.004^{* * *}$ & -0.001 & -0.0007 & $-0.001^{* *}$ & 0.001 & -0.001 & -0.001 & 0.001 \\
& $(0.00)$ & $(0.00)$ & $(0.00)$ & $(0.00)$ & $(0.00)$ & $(0.00)$ & $(0.00)$ & $(0.00)$ \\
COST_INCOME & $0.00001^{*}$ & $0.0001^{* *}$ & $0.0001^{* * *}$ & $3.63 \mathrm{e}-05$ & $-7.83 \mathrm{e}-05$ & $-6.55 \mathrm{e}-05$ & $-3.93 \mathrm{e}-05$ & $-2.54 \mathrm{e}-05$ \\
& $(0.00)$ & $(0.00)$ & $(0.00)$ & $(0.00)$ & $(0.00)$ & $(0.00)$ & $(0.00)$ & $(0.00)$ \\
SIZE & $-0.007^{*}$ & -0.001 & -0.001 & -0.001 & $0.012^{* *}$ & $0.006^{*}$ & $0.004^{*}$ & 0.001 \\
& $(0.00)$ & $(0.00)$ & $(0.00)$ & $(0.00)$ & $(0.00)$ & $(0.00)$ & $(0.00)$ & $(0.00)$ \\
Observations & 42 & 42 & 42 & 42 & 42 & 42 & 42 & 42 \\
R-squared & 0.511 & 0.199 & 0.378 & 0.235 & 0.242 & 0.128 & 0.095 & 0.106 \\
\hline
\end{tabular}

Notes. Table $7 \mathrm{~b}$ shows the results of the regression model run on CARs estimated around the announcement of the referendum date (20 February 2016). The dependent variables are CARs quantified in the event windows showing the highest significance in the event study analysis for subsamples of UK banks. Bank-specific variables are the following: equity over total assets (E_TA) as measure of capitalization, ROA as measure of profitability, the COST_INCOME ratio as proxy of bank cost efficiency, the natural logarithm of total revenues (SIZE) as proxy of firm size. ${ }^{*},{ }^{* *},{ }^{* * *}$ denote the statistical significance at $10 \%, 5 \%$ and $1 \%$ level, respectively.

Second, we attempt to explain CARs estimated around the referendum day. Tables $8 \mathrm{a}$ and $8 \mathrm{~b}$ reports the evidence for EU and UK banks, respectively, that are quite similar. Specifically, even if some bank-specific variables display statistically significant coefficients, their magnitude is very low (lower than $0.01 \%$ ) to consider them as variables able to significantly impact on CARs observe.

Analysis of the subsample of other European banks (Table 8a), the size and the profitability are the only variables that show a statistically significant coefficient with a consistent magnitude with regard to the EU banks. Before the referendum results, when the expected results was the remain, larger banks show higher CAR; while, after the referendum result, when the Brexit result has been announced, the negative effect on CAR was more pronounce for smaller banks. Referring to the bank profitability, ROA is statistically significant only after the referendum result and our results show a positive and statistically significant relationship between ROA and CAR, suggesting that banks with higher profitability show higher CAR. In particular, looking at the longer EW $(0,+10)$ and $(0,+5)$, in front of an increase of $1 \%$ of ROA, the CAR increases of $0.9 \%$. The effect is less strong as the EWs become shorter.

With regard to the geographical area, GIIPS shows positive, high, and statistically significant coefficients. This result is consistent with the evidence reported for the previous event. If in a scenario in which "remain" seemed the obvious outcome, banks operating in the GIIPS countries were considered to reap the highest benefits from the reformed Europe that Cameron imagined; therefore, after the outcome of the referendum, these banks stood to suffer the greatest disadvantages from Brexit. This result confirms the evidence reported by Smales (2017) and could be attributed to the fragile banking sector of Greece, Italy, Portugal, Spain, and Ireland, which still show higher non-performing loans in their balance sheets, compared with the EU average.

Looking at UK banks results (Table 8b), the bank profitability does not show any statistically significant results, while size shows a positive and statistically significant relationship before the referendum result and a negative and statistically significant relationship after the referendum result. These results suggest that when the shareholders expected the remain result, the shareholder reaction was greater for larger banks, while, after the announcement of Brexit result, the shareholder reaction was stronger for smaller banks.

Table 8a. Regression analysis: investor reaction to the referendum result announcement (EU banks) 


\begin{tabular}{lllllllll}
\hline & CAR(-10,-1) & CAR(-5,-1) & CAR(-3,-1) & CAR(-1,0) & CAR $(0,+10)$ & CAR $(0,+5)$ & CAR $(0,+3)$ & CAR $(0,+1)$ \\
\hline Constant & $-0.088^{*}$ & $-0.147^{* * *}$ & $-0.079^{* * *}$ & $-0.086^{* * *}$ & 0.087 & 0.052 & 0.076 & 0.034 \\
& $(0.04)$ & $(0.03)$ & $(0.02)$ & $(0.02)$ & $(0.07)$ & $(0.05)$ & $(0.05)$ & $(0.04)$ \\
E_TA & 0.000 & 0.001 & 0.001 & 0.000 & -0.001 & $-0.001^{* *}$ & $-0.001^{* *}$ & $-0.001^{* * *}$ \\
& $(0.00)$ & $(0.00)$ & $(0.00)$ & $(0.00)$ & $(0.00)$ & $(0.00)$ & $(0.00)$ & $(0.00)$ \\
ROA & 0.001 & 0.001 & 0.000 & 0.001 & $0.009 * *$ & $0.009^{* * *}$ & $0.007^{* * *}$ & $0.006^{* * *}$ \\
& $(0.00)$ & $(0.00)$ & $(0.00)$ & $(0.00)$ & $(0.00)$ & $(0.00)$ & $(0.00)$ & $(0.00)$ \\
COST_INCOME & $0.001^{* *}$ & $0.001^{* *}$ & 0.000 & $0.001^{* * *}$ & $0.001^{* * *}$ & $0.001^{* * *}$ & $0.001^{* * *}$ & $0.001^{* * *}$ \\
& $(0.00)$ & $(0.00)$ & $(0.00)$ & $(0.00)$ & $(0.00)$ & $(0.00)$ & $(0.00)$ & $(0.00)$ \\
SIZE & 0.003 & $0.010^{* * *}$ & $0.006^{* * *}$ & $0.005^{* * *}$ & $-0.010^{* *}$ & $-0.006^{* *}$ & $-0.008^{* * *}$ & $-0.005^{* *}$ \\
& $(0.002)$ & $(0.00)$ & $(0.00)$ & $(0.00)$ & $(0.00)$ & $(0.00)$ & $(0.00)$ & $(0.00)$ \\
GIIPS & -0.013 & $0.041^{* * *}$ & $0.019 * * *$ & $0.022^{* * *}$ & $0.110^{* * *}$ & $0.068^{* * *}$ & $0.060^{* * *}$ & $0.062^{* * *}$ \\
& $(0.01)$ & $(0.01)$ & $(0.00)$ & $(0.00)$ & $(0.02)$ & $(0.01)$ & $(0.01)$ & $(0.01)$ \\
EAST_COUNTRIES & 0.011 & -0.001 & 0.006 & 0.012 & 0.018 & 0.032 & 0.019 & 0.001 \\
& $(0.01)$ & $(0.01)$ & $(0.00)$ & $(0.00)$ & $(0.02)$ & $(0.02)$ & $(0.01)$ & $(0.01)$ \\
Observations & 154 & 154 & 154 & 154 & 154 & 154 & 154 & 154 \\
R-squared & 0.086 & 0.312 & 0.277 & 0.312 & 0.373 & 0.344 & 0.413 & 0.523 \\
\hline
\end{tabular}

Notes. Table 8a shows the results of the regression model run on CARs estimated around the referendum date (23 June 2016). The dependent variables are CARs quantified in the event windows showing the highest significance in the event study analysis for the subsample of EU banks. Bank-specific variables are the following: equity over total assets (E_TA) as measure of capitalization, ROA as measure of profitability, the COST_INCOME ratio as proxy of bank cost efficiency, the natural logarithm of total revenues (SIZE) as proxy of firm size. GIIPS is a dummy variable equals 1 when bank is placed in Greece, Italy, Portugal, Spain or Ireland, 0 otherwise; EAST_COUNTRIES is a dummy variable equals 1 when bank is placed in Bulgaria, Croatia, Poland, Czech Republic, Romania and Hungary, and 0 otherwise. ${ }^{*},{ }^{* *}$, ${ }^{* * *}$ denote the statistical significance at $10 \%, 5 \%$ and $1 \%$ level, respectively.

Table 8b. Regression analysis: investor reaction to the referendum result announcement (UK banks)

\begin{tabular}{lllllllll}
\hline & CAR(-10,-1) & CAR $(-5,-1)$ & $\mathrm{CAR}(-3,-1)$ & $\mathrm{CAR}(-1,0)$ & $\mathrm{CAR}(0,+10)$ & $\mathrm{CAR}(0,+5)$ & $\mathrm{CAR}(0,+3)$ & $\mathrm{CAR}(0,+1)$ \\
\hline Constant & -0.050 & -0.0680 & -0.051 & -0.0240 & $0.002^{* * *}$ & $0.001^{* * *}$ & $0.001^{* * *}$ & $0.001^{* * *}$ \\
& $(0.03)$ & $(0.04)$ & $(0.02)$ & $(0.01)$ & $(0.00)$ & $(0.00)$ & $(0.00)$ & $(0.00)$ \\
\multirow{2}{*}{ E_TA } & -0.000 & -0.000 & -0.000 & -0.000 & -0.002 & 0.000 & -0.001 & -0.001 \\
& $(0.00)$ & $(0.00)$ & $(0.00)$ & $(0.00)$ & $(0.00)$ & $(0.00)$ & $(0.00)$ & $(0.00)$ \\
\multirow{2}{*}{ ROA } & -0.000 & -0.000 & 0.000 & 0.000 & -0.000 & -0.000 & -0.000 & -0.000 \\
& $(0.00)$ & $(0.00)$ & $(0.00)$ & $(0.00)$ & $(0.00)$ & $(0.00)$ & $(0.00)$ & $(0.00)$ \\
COST_INCOME) & $-1.64 \mathrm{e}-05$ & $-2.51 \mathrm{e}-06$ & $-2.23 \mathrm{e}-05$ & $2.55 \mathrm{e}-05$ & 0.003 & 0.003 & -0.001 & -0.001 \\
& $(0.00)$ & $(0.00)$ & $(0.00)$ & $(0.00)$ & $(0.00)$ & $(0.00)$ & $(0.01)$ & $(0.00)$ \\
SIZE & $0.004 * *$ & $0.008^{* * *}$ & $0.006^{* * *}$ & $0.003 * * *$ & $-0.269^{*}$ & $-0.209 *$ & -0.150 & -0.072 \\
& $(0.00)$ & $(0.00)$ & $(0.00)$ & $(0.00)$ & $(0.15)$ & $(0.11)$ & $(0.12)$ & $(0.06)$ \\
Observations & 44 & 44 & 44 & 44 & 43 & 43 & 43 & 43 \\
R-squared & 0.252 & 0.508 & 0.530 & 0.468 & 0.371 & 0.334 & 0.295 & 0.255 \\
\hline
\end{tabular}

Notes. Table $8 \mathrm{~b}$ shows the results of the regression model run on CARs estimated around the referendum date (23 June 2016). The dependent variables are CARs quantified in the event windows showing the highest significance in the event study analysis for the subsample of UK banks. Bank-specific variables are the following: equity over total assets (E_TA) as measure of capitalization, ROA as measure of profitability, the COST_INCOME ratio as proxy of bank cost efficiency, the natural logarithm of total revenues (SIZE) as proxy of firm size. ${ }^{*},{ }^{* *},{ }^{* * *}$ denote the statistical significance at $10 \%, 5 \%$ and $1 \%$ level, respectively.

Our last regression analysis focuses on the day on which Theresa May become Prime Minister (11 July 2016). Table 9a and Table 9b report our results and show very similar results to the evidence reported for the previous event. However, in this case, both for EU banks and UK banks, the bank-specific variables display a very low magnitude also in those case in which the variables show a statistically significant relationship with CAR. The GIIPS variable shows instead positive, high, and statistically significant coefficients. This over-reaction of banks operating in Greece, Italy, Portugal, Spain, and Ireland is consistent with the evidence reported in the previous two Brexit-related events. Specifically, the election of Theresa May was considered "good news" by European bank shareholders, who, at that time, identified in Brexit several opportunities for the Euro-area to attract potential 
financial business from London. In this context, banks operating in the GIIPS countries were considered to reap the largest benefits from the UK leaving the EU.

Table 9a. Regression analysis: investor reaction to the appointment of Theresa May announcement (EU banks)

\begin{tabular}{llllll}
\hline & CAR(-1,0) & CAR $(0,+10)$ & CAR $(0,+5)$ & CAR $(0,+3)$ & CAR $(0,+1)$ \\
\hline Constant & -0.040 & 0.011 & 0.043 & 0.009 & 0.039 \\
& $(0.03)$ & $(0.06)$ & $(0.06)$ & $(0.06)$ & $(0.06)$ \\
E_TA & -0.000 & -0.001 & -0.001 & -0.001 & -0.001 \\
& $(0.00)$ & $(0.00)$ & $(0.001)$ & $(0.00)$ & $(0.00)$ \\
ROA & -0.001 & -0.001 & -0.002 & -0.003 & -0.002 \\
& $(0.00)$ & $(0.00)$ & $(0.00)$ & $(0.00)$ & $(0.00)$ \\
COST_INCOME & 0.000 & $-0.001^{* *}$ & $-0.001^{* *}$ & $-0.001^{* *}$ & $-0.001^{* *}$ \\
& $(0.00)$ & $(0.00)$ & $(0.00)$ & $(0.00)$ & $(0.00)$ \\
SIZE & $0.004^{* *}$ & $0.001^{* *}$ & 0.002 & 0.004 & 0.001 \\
& $(0.00)$ & $(0.00)$ & $(0.00)$ & $(0.00)$ & $(0.00)$ \\
GIIPS & $0.041^{* * *}$ & $0.057^{* * *}$ & $0.064^{* * *}$ & $0.057^{* * *}$ & $0.041^{* *}$ \\
& $(0.01)$ & $(0.01)$ & $(0.01)$ & $(0.01)$ & $(0.01)$ \\
EAST_COUNTRIES & -0.004 & -0.002 & -0.008 & -0.022 & -0.008 \\
& $(0.01)$ & $(0.02)$ & $(0.02)$ & $(0.02)$ & $(0.02)$ \\
Observations & 154 & 154 & 154 & 154 & 154 \\
R-squared & 0.219 & 0.205 & 0.203 & 0.221 & 0.120 \\
\hline
\end{tabular}

Notes. Table 9a shows the results of the regression model run on CARs estimated around the election of Theresa May as Prime Minister (11 July 2016). The dependent variables are CARs quantified in the event windows showing the highest significance in the event study analysis for the subsample of EU banks. Bank-specific variables are the following: equity over total assets (E_TA) as measure of capitalization, ROA as measure of profitability, the COST_INCOME ratio as proxy of bank cost efficiency, and the natural logarithm of total revenues (SIZE) as proxy of firm size. GIIPS is a dummy variable equals 1 when bank is placed in Greece, Italy, Portugal, Spain or Ireland, 0 otherwise; EAST_COUNTRIES is a dummy variable equals 1 when bank is placed in Bulgaria, Croatia, Poland, Czech Republic, Romania and Hungary, and 0 otherwise. ${ }^{*},{ }^{* *},{ }^{* * *}$ denote the statistical significance at $10 \%, 5 \%$ and $1 \%$ level, respectively.

Table 9b. Regression analysis: investor reaction to the appointment of Theresa May announcement (UK banks)

\begin{tabular}{|c|c|c|c|c|c|}
\hline & CAR(-1,0) & $\operatorname{CAR}(0,+10)$ & $\mathrm{CAR}(0,+5)$ & $\operatorname{CAR}(0,+3)$ & $\operatorname{CAR}(0,+1)$ \\
\hline \multirow[t]{2}{*}{ Constant } & -0.023 & 0.070 & 0.030 & 0.024 & -0.013 \\
\hline & $(0.04)$ & $(0.07)$ & $(0.06)$ & $(0.05)$ & $(0.06)$ \\
\hline \multirow[t]{2}{*}{ E_TA } & $-0.0003 *$ & $-0.001 * *$ & $-0.001 * *$ & $-0.001 * *$ & -0.000 \\
\hline & $(0.00)$ & $(0.00)$ & $(0.00)$ & $(0.00)$ & $(0.00)$ \\
\hline \multirow[t]{2}{*}{ ROA } & 0.000 & $0.0002 * * *$ & $0.0002 * *$ & $0.0002 * *$ & 0.001 \\
\hline & $(0.00)$ & $(0.00)$ & $(0.00)$ & $(0.00)$ & $(0.00)$ \\
\hline \multirow[t]{2}{*}{ COST_INCOME } & $-6.10 \mathrm{e}-05$ & $1.00 \mathrm{e}-05$ & $1.73 e-06$ & $-8.55 e-07$ & $-1.68 \mathrm{e}-05$ \\
\hline & $(0.00)$ & $(0.00)$ & $(0.00)$ & $(0.00)$ & $(0.00)$ \\
\hline \multirow[t]{2}{*}{ SIZE } & $0.005 * *$ & 0.003 & 0.004 & 0.004 & $0.006^{*}$ \\
\hline & $(0.00)$ & $(0.00)$ & $(0.00)$ & $(0.00)$ & $(0.00)$ \\
\hline Observations & 43 & 43 & 43 & 43 & 43 \\
\hline $\mathrm{R}$-squared & 0.404 & 0.354 & 0.357 & 0.366 & 0.263 \\
\hline
\end{tabular}

Notes. Table 9b shows the results of the regression model run on CARs estimated around the election of Theresa May as Prime Minister (11 July 2016). The dependent variables are CARs quantified in the event windows showing the highest significance in the event study analysis for the subsample of UK banks. Bank-specific variables are the following: equity over total assets (E_TA) as measure of capitalization, ROA as measure of profitability, the COST_INCOME ratio as proxy of bank cost efficiency, and the natural logarithm of total revenues (SIZE) as proxy of firm size. ${ }^{*},{ }^{* *},{ }^{* * *}$ denote the statistical significance at $10 \%, 5 \%$ and $1 \%$ level, respectively.

Our results show, overall, that the shareholder reaction to different events related to Brexit depends more on the country in which the bank operates than on firm-specific variables. This is consistent with the evidence obtained 
by the univariate analyses. CARs registered in our event studies are in fact high and robust, suggesting that political risk related to Brexit is key to explaining the stock market performance around different events. In this context, bank characteristics are considered not to (or to only very slightly) determine bank shareholder reactions.

Specifically, size and profitability are the only bank characteristics that contribute slightly to the explanation for the observed stock returns: the larger the bank, the greater its shareholder reaction, as suggested by Davies and Studnicka (2018) and the higher the bank profitability, the higher the stock market reaction. The evidence for country-specific variables is, in contrast, stronger. Specifically, banks operating in the GIIPS countries are shown to over-react to the announcement of Brexit-related events. This can be explained by the fragile banking systems of Greece, Italy, Portugal, Spain, and Ireland, which make them particularly exposed to political risk.

Although some bank characteristics are statistically significant, when we observe the variables coefficients, our results suggest that the geographical area (GIIPS) affects more the change of CAR observed.

\section{Additional Analysis and Robustness Checks}

In order to enrich our analysis, we conducted additional event studies on other events related to Brexit following the election of Theresa May. These events have been selected as the most cited by the international press about Brexit in the period from November 2016 to July 2018. Specifically, we investigated the impact of the following announcements on UK and other European bank stock returns:

- 11/4/2016: Stephen Phillips resigned as Conservative MP following the High Court ruling that Article 50 should be put to a vote in the House of Commons;

- 1/17/2017: Theresa May gave a speech outlining her aim for what has become known as a "hard Brexit", setting out the Government's 12-point "Plan for Britain" and her negotiating red lines, in the process ruling out UK membership of the EU customs union;

- 3/29/2017: The Prime Minister May triggered Article 50 of the Lisbon Treaty, formally kick-starting a two-year countdown to the UK exiting the bloc;

- 6/8/2017: Theresa May lost her parliamentary majority and was forced to make a deal with the Democratic Unionist Party to stay in power;

- 6/19/2017: The lead negotiators, David Davis and Michel Barnier, representing the UK and the European Commission, began discussions in Brussels;

- 21/8/2017: After negotiations in Brussels, the UK and the EU agreed a deal on the UK's so-called divorce bill, covering both EU and UK citizens' rights and the Northern Irish "backstop";

- 7/9/2018: Boris Johnson signed his resignation letter at the official residence of the Foreign Secretary in London, claiming that the UK was heading "for the status of a colony" if Theresa May's soft Brexit plans were adopted.

Our analysis shows that, because the estimated CARs are not statistically significant, the political events occurring on $1 / 17 / 2017,6 / 19 / 2017,21 / 8 / 2017$, and $7 / 9 / 2018$ are completely uninformative. This means that the announcement of Theresa May's aim of a "hard Brexit", the formal beginning in Brussels of the discussions between UK and the European Commission, the agreement about the deal on the UK's divorce bill, and the resignation letter of Boris Johnson did not come as surprises to the market. This probably reflects the fact that these events occurred after widespread debate and controversy, and following formal negotiations, so that the market was likely able to price the information before it was officially announced.

However, our findings for 11/4/2016, 3/29/2017, and 6/8/2017 show negative statistically significant mean CARs in the event windows prior to Day 0, both for UK and other European banks. This means that bank shareholders negatively priced the news of the resignation of Stephen Phillips, the formal kick-starting of the two-year countdown to the UK exit from the EU, and Theresa May losing her parliamentary majority, and, further, that financial markets anticipated this news. The mean CARs registered for these three events ranges, however, from $-1 \%$ to $-2 \%$. This shows that bank shareholder reaction to the information was negative, but fairly weak. This is consistent with the evidence reported by Davies and Studnicka (2018), who show that events after the Brexit referendum revealed little useful information. Moreover, our results for European banks support the findings by Aristeidis and Elias (2018). They demonstrate that there was an immediate significant contagion effect from the Brexit vote to other stock markets because of the increased uncertainty; this was, however, very limited over time.

For the OLS regressions, as robustness checks, in addition to the variables presented in our regression model, we include other bank characteristics such as non-performing loans over gross loans (as proxy of credit portfolio quality), total capital ratio (as proxy of regulatory capital), and other profitability measures, i.e. the return on equity and the net interest margin. However, these variables do not explain our CARs and, when they are 
inserted into the model, the adjusted R-squared is lower than that observed in the previous section (Note 5).

\section{Discussion and Conclusions}

The outcome of the 2016 Brexit referendum has been the most disruptive event for the financial system since the financial crisis of 2008. Largely unexpected and previously considered as an emerging risk with low probability, Brexit, together with all the related challenges, is likely to continue to affect bank business models and bank operations, depending on the final results of the negotiations between UK and the EU and the consequent new shape of the European economic and financial landscape.

In order to assess whether capital markets priced the risk related to Brexit and anticipated its effects on the banking business, we tested the stock market reaction to three events surrounding the referendum, in the light of their potential economic impact: the announcements of the referendum date and the referendum result, and Theresa May becoming Prime Minister. We focused on both UK and other European-listed banks.

Across the EU, the bank stock market anticipated the news about the referendum date. This information was positively and almost equally priced by both UK and other European banks before its official announcement. This positive reaction could be explained considering that 20 February 2016 was the date on which Cameron announced that he would keep his promise, made on 2013, to hold a future referendum on the UK's continued membership of the EU. The information about the referendum date was positively priced also after its official announcement by all European bank shareholders, but the reaction in other European countries was stronger than in the UK. This could be attributed to the content of Cameron's speech on 20 February 2016, which was not only pro-remain, but also significantly Europeanist, suggesting a scenario in which "remain" seemed the obvious outcome.

This scenario continued until 23 June 2016. As expected, in the days before the vote, both UK and other European bank shareholders positively priced the information on the referendum. However, the referendum outcome was a complete surprise to the market: on 24 June 2016, both Standard \& Poor's and Fitch Ratings downgraded the UK's rating to AA and the IMF forecasted reduced global economic growth, and especially for the UK. All European bank shareholders negatively priced this unexpected news which produced significant political uncertainty. The reaction to the vote was stronger in the UK than in other European countries: Brexit in fact threatened the supremacy of London as Europe's long-standing leading financial center.

Following the resignation of David Cameron, on 11 July 2016, Theresa May became Prime Minister. She was described by the press and, consequently, perceived by investors, as a true leader: charismatic and credible, she immediately promised to build a "better Britain" and to make the UK's exit from the EU a "success". Therefore, the election of Theresa May was considered "good news" by bank shareholders, both in the UK and in the other European countries. This event, making the Brexit scenario more certain, on the one hand allowed UK bank shareholders to immediately assess the effect on the country's future. On the other hand, in this context, bank shareholders of other European countries identified opportunities for the Euro-area to attract potential financial business from London.

We ran some additional event studies on other events related to Brexit following the election of Theresa May in the period from November 2016 to July 2018. These events revealed very little useful information: the Brexit vote produced an immediate significant contagion effect on the stock markets because of the increased uncertainty, but this was very limited over time.

Our cross-sectional analyses show that shareholder reaction to different events related to Brexit depended more on the countries in which the banks operate than on firm-specific variables. Specifically, banks operating in the GIIPS countries over-reacted to the announcement of Brexit-related events, as their fragile banking system made them particularly exposed to political risk.

The contributions of our study to the existing literature are numerous. Even if, in addition to political risk, different kind of risk related to Brexit, such as the competitive risk, can impact the banking stocks, our study offers empirical evidence of the sensitivity of the banking industry to geo-political risk, thus supporting the focus of the ECB supervisors on the issue. Moreover, the paper analyzes the impact of Brexit on stock market returns considering three different significant dates: unlike most previous literature, we focus in fact on a longer time horizon, ranging from 20 February 2016 to 7 September 2018. We also study the effect of Brexit both on the UK and in other European countries and attempt to explain the differences between these countries. Finally, we analyze the impact of firm- and country-specific characteristics on bank shareholder reactions.

The results of the event studies have further important regulatory and managerial implications. New political risks and geo-political uncertainties are likely to affect the banking sector worldwide, and, in accordance with a forward-looking and long-term strategic perspective, should be appropriately included into scenario analysis and 
risk management frameworks. In this regard, supervisors seem to be ahead of banks in anticipating these future challenges and encouraging supervised entities to prepare to face the related risks. Although international political changes seem to directly affect larger banks in most instances, small- and medium-sized intermediaries are also likely to experience their effects because of changes in market and competitive conditions and transformations in their counterparts' business models and economics. Therefore, for all kinds of financial institutions, the ability to assess and manage geo-political risk is of utmost importance and needs to be taken into account in strategic planning and risk management.

Our study represents a first attempt to investigate the effects of three events related to Brexit on stock prices of UK and European banks. However, our research shows some limitations. First, our sample is limited to listed banks. Second, the analysis is focused only on the stock market and does not consider other markets, as the bond market. Moreover, the effects on UK and other European banks are investigated overall, without considering specifically export and import trends of banks.

Further research could expand on our sample by focusing also on non-listed banks and on the bond market. Moreover, future studies could investigate the effects of Brexit on UK banks oriented to export and on other European banks specifically oriented to import from the UK.

\section{References}

Aristeidis, S., \& Elias, K. (2018). Empirical analysis of market reactions to the UK's referendum results-How strong will Brexit be? Journal of International Financial Markets, Institutions and Money, 53, 263-286. https://doi.org/10.1016/j.intfin.2017.12.003

Armour, J. (2017). Brexit and financial services. Oxford Review of Economic Policy, 33(1), 54-69. https://doi.org/10.1093/oxrep/grx014

Arshad, S., Rizvi, S. A. R., \& Haroon, O. (2019). Impact of Brexit vote on the London stock exchange: A sectorial analysis of its volatility and efficiency. Finance Research Letters. https://doi.org/10.1016/j.frl.2019.07.013

Baur, D. G., Dimpfl, T., \& Treepongkaruna, S. (2018). A storm but no damage? A two-country equity and currency market perspective of Brexit. https://doi.org/10.1007/s10272-019

Belke, A., Dubova, I., \& Osowski, T. (2018). Policy uncertainty and international financial markets: the case of Brexit. Applied Economics, 50(34-35), 3752-3770. https://doi.org/10.1080/00036846.2018.1436152

Białkowski, J., Gottschalk, K., \& Wisniewski, T.P. (2008). Stock market volatility around national elections. Journal of Banking and Finance, 32(9), 1941-1953. https://doi.org/10.1016/j.jbankfin.2007.12.021

Boehmer, E., Musumeci, J., \& Poulsen, A. (1991). Event-study methodology under conditions of event-induced variance. Journal of Financial Economics, 30, 253-272. https://doi.org/10.1016/0304-405X(91)90032-F

Boutchkova, M., Doshi, H., Durnev, A., \& Molchanov, A. (2016). Precarious politics and return volatility. Review of Financial Studies, 25(4), 1111-1154. https://doi.org/10.2139/ssrn.1317834

Brogaard, J., \& Detzel, A. (2015). The asset-pricing implications of government economic policy uncertainty. Managerial Science, 61(1), 3-18. https://doi.org/10.1287/mnsc.2014.2044

Campbell R. Harvey, Yan Liu, Heqing Zhu, (2016) ... and the Cross-Section of Expected Returns. The Review of Financial Studies, 29(1), 5-68. https://doi.org/10.1093/rfs/hhv059

Campbell, J. Y., Lo, A. W., \& MacKinley, A. C. (1997). The econometrics of financial markets. Princeton: Princeton University Press.

Campello, M., Cortes, G., d'Almeida, F., \& Kankanhalli, G. (2018). Exporting uncertainty: the impact of Brexit on corporate America.

Chabot, M., Bertrand, J. L., \& Thorez, E. (2019). Resilience of United Kingdom financial institutions to major uncertainty: A network analysis related to the Credit Default Swaps market. Journal of Business Research, 101, 70-82. https://doi.org/10.1016/j.jbusres.2019.04.003

Chung, K. H., \& Chuwonganant, C. (2018). Market volatility and stock returns: The role of liquidity providers. Journal of Financial Markets, 37, 17-34. https://doi.org/10.1016/j.finmar.2017.07.002

Davies, R. B., \& Studnicka, Z. (2018). The heterogeneous impact of Brexit: early indications from the FTSE. European Economic Review, 110, 1-17. https://doi.org/10.1016/j.euroecorev.2018.08.003

Dibiasi, A., Abberger, K., Siegenthaler, M., \& Sturm, J. E. (2018). The effects of policy uncertainty on investment: evidence from the unexpected acceptance of a far-reaching referendum in Switzerland. European Economic Review, 104, 38-67. https://doi.org/10.1016/j.euroecorev.2018.01.002 
Errunza, V., \& Hogan, K. (1998). Macroeconomic determinants of European stock market volatility. European Financial Management, 4(3), 361-377. https://doi.org/10.1111/1468-036X.00071

Fama, E. F. (1965). The behavior of stock-market prices. The Journal of Business, 38(1), 34-105.

Fama, E. F. (1970). Efficient capital markets: A review of theory and empirical work. The journal of Finance, 25(2), 383-417. https://doi.org/10.2307/2325486

Goodell, J. W., \& Vähämaa, S. (2013). US presidential elections and implied volatility: the role of political uncertainty. Journal of Banking \& Finance, $37(3), \quad$ 1108-1117. https://doi.org/10.1016/j.jbankfin.2012.12.001

Guldiken, O., Tupper, C., Nair, A., \& Yu, H. (2017). The impact of media coverage on IPO stock performance. Journal of Business Research, 72, 24-32. https://doi.org/10.1016/j.jbusres.2016.11.007

He, Y., Lin, H., Wu, C., \& Dufrene, U. B. (2009). The 2000 presidential election and the information cost of sensitive versus non-sensitive S\&P 500 stocks. Journal of Financial Markets, 12(1), 54-86. https://doi.org/10.1016/j.finmar.2008.04.004

Hill, P., Korczak, A., \& Korczak, P. (2019). Political uncertainty exposure of individual companies: the case of the Brexit referendum. Journal of Banking \& Finance, 100, 58-76. https://doi.org/10.1016/j.jbankfin.2018.12.012

House of Lords EU Committee. (2016). Brexit: financial services. 9th Report of Session 2016-17, HL Paper 81.

Howarth, D., \& Quaglia, L. (2018). Brexit and the battle for financial services. Journal of European Public Policy 25(8), 1118-1136. https://doi.org/10.1080/13501763.2018.1467950

Kadiric, S., \& Korus, A. (2019). The effects of Brexit on credit spreads: evidence from UK and Eurozone corporate bond markets. International Economics and Economic Policy, 16(1), 65-102. https://doi.org/10.1007/s10368-018-00424-z

Krause, T., Noth, F., Tonzer, L. (2016). Brexit (probability) and effects on financial market stability (No. 5/2016). IWH Online.

MacKinlay, A. C., (1997). Event studies in Economics and Finance. Journal of Economic Literature, 35, 13-39.

Mei, J., \& Guo, L. (2004). Political uncertainty, financial crisis and market volatility. European Financial Management, 10(4), 639-657. https://doi.org/10.1111/j.1354-7798.2004.00269.x

Moore, M., \& Ramsay, G. (2017). UK media coverage of the 2016 EU Referendum campaign. King's College London.

Nippani, S., \& Medlin, W. B. (2002). The 2000 presidential election and the stock market. Journal of Economics and Finance, 26(2), 162-169. https://doi.org/10.1007/BF02755983

Oehler, A., Horn, M., \& Wendt, S. (2017). Brexit: short-term stock price effects and the impact of firm-level internationalization. Finance Research Letters, 22, 175-181. https://doi.org/10.1016/j.frl.2016.12.024

Oliver Wyman (2016). The impact of the UK's exit from the EU on the UK-based financial services sector. Report Commissioned for The City UK.

Pantzalis, C., Stangeland, D. A., \& Turtle, H. J. (2000). Political elections and the resolution of uncertainty: the international evidence. Journal of Banking and Finance, 24(10), 1575-1604. https://doi.org/10.1016/S0378-4266(99)00093-X

Pastor, L., \& Veronesi, P. (2012). Uncertainty about government policy and stock prices. Journal of Finance, 67(4), 1219-1264. https://doi.org/10.1111/j.1540-6261.2012.01746.x

Ramiah, V., Huy, N. A., \& Pham, M. I. (2017). The sectorial effects of Brexit on the British economy: early evidence from the reaction of the stock market. Applied Economics, 49, 2508-2514. https://doi.org/10.1080/00036846.2016.1240352

Santa-Clara, P., \& Valkanov, R. (2003). The presidential puzzle: political cycles and the stock market. Journal of Finance, 58(5), 1841-1872. https://doi.org/10.1111/1540-6261.00590

Schiereck, D., Kiesel, F., \& Kolaric, S. (2016). Brexit: (Not) another Lehman moment for banks? Finance Research Letters, 19, 291-297. https://doi.org/10.1016/j.frl.2016.09.003

Schwab, K. (2018). November. The global competitiveness report 2018. In World Economic Forum (pp. 9-14).

Shahzad, K., Rubbaniy, G., Lensvelt, M. A. P. E., \& Bhatti, T. (2019). UK's stock market reaction to Brexit process: 
a tale of two halves. Economic Modelling, 80, 275-283. https://doi.org/10.1016/j.econmod.2018.11.013

Sharpe, W. F. (1963). A simplified model for portfolio analysis. Management Science, 9(2), 277-293.

Škrinjarić, T. (2020). Dynamic portfolio optimization based on grey relational analysis approach. Expert Systems With Applications, 147.

Smales, L. A. (2015). Better the devil you know: The influence of political incumbency on Australian financial market uncertainty. Research in International Business and Finance, 33, 59-74. https://doi.org/10.1016/j.ribaf.2014.06.002

Smales, L. A. (2016). The role of political uncertainty in Australian financial markets. Accounting \& Finance, 56(2), 545-575. https://doi.org/10.1111/acfi.12107

Smales, L. A. (2017). "Brexit": a case study in the relationship between political and financial market uncertainty. International Review of Finance, 17(3), 451-459. https://doi.org/10.1111/irfi.12100

Tielmann, A., \& Schiereck, D. (2017). Arising borders and the value of logistic companies: evidence from the Brexit referendum in Great Britain. Finance Research Letters, 20, 22-28. https://doi.org/10.1016/j.frl.2016.08.006

Tokarski, P., \& Funk, S. (2019). Non-euro countries in the EU after Brexit: between fear of losing of political influence and Euro accession. https://doi.org/10.18449/2019C03

Wielechowski, M., \& Czech, K. (2016). Brexit related uncertainty for United Kingdom economy. Oeconomia 15(4), 171-18

\section{Notes}

Note 1. The full transcript of the speech is available on https://www.independent.co.uk/news/uk/politics/eu-referendum-brexit-latest-live-david-cameron-full-speech-re main-leave-a7093426.html

Note 2. https://www.bankingsupervision.europa.eu/ecb/pub/ra/html/ssm.ra2020 a9164196cc.en.html\#toc3

Note 3. We exclude Denmark and Sweden because, although these countries do not belong to the Eurozone, their economic growth rate and banking sector characteristics are similar to those of the Eurozone banks. Denmark and Sweden are in fact among the most competitive countries in the world (Schwab, 2018). In contrast, the euro-out countries are similar in that they are currently plagued by political instability and institutional weaknesses, and still base their competitiveness on low wages (Tokarski \& Funk, 2019).

Note

4.

See

https://www.newstatesman.com/politics/uk/2016/06/latest-brexit-betting-what-are-odds-eu-referendum for different betting prices.

Note 5. Results on robustness checks are not reported in this paper, but are available upon request.

\section{Copyrights}

Copyright for this article is retained by the author(s), with first publication rights granted to the journal.

This is an open-access article distributed under the terms and conditions of the Creative Commons Attribution license (http://creativecommons.org/licenses/by/4.0/). 